\title{
Petrogenesis of fractionated nested granite intrusions: the Sedmihoří Composite Stock (Bohemian Massif)
}

\author{
Jakub TRUBAČ ${ }^{*}$, Vojtěch JANOUŠEK ${ }^{2,3}$, Axel GERDES ${ }^{4}$ \\ ${ }^{1}$ Institute of Geochemistry, Mineralogy and Mineral Resources, Charles University, Albertov 6, 12843 Prague 2, Czech Republic; \\ jakub.trubac@gmail.com \\ ${ }^{2}$ Czech Geological Survey, Klárov 3, 11821 Prague 1, Czech Republic \\ ${ }^{3}$ Institute of Petrology and Structural Geology, Charles University, Albertov 6, 12843 Prague 2, Czech Republic \\ ${ }^{4}$ Institut für Geowissenschaften, Goethe University Frankfurt, Altenhöferallee 1, D-60438, Frankfurt am Main, Germany \\ * Corresponding author
}

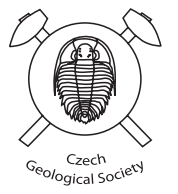

The post-tectonic Sedmihoří Stock (SCS) is a circular body in plan-view, made up of three nested units: (i) 'Outer granite' (OG), less fractionated Kfs-phyric Bt monzogranite (326.2 $\pm 1.2 \mathrm{Ma}(2 \sigma)$, LA ICP-MS Zrn), (ii) 'Inner granite' (IG), more evolved Bt-Ms monzogranite (326.6 $\pm 1.2 \mathrm{Ma}$ ), and (iii) innermost leucogranite ('LG'), fine-grained Tur-Ms leucogranite. All the varieties of this body are silica-rich $\left(\mathrm{SiO}_{2}>71 \mathrm{wt} . \%\right)$ and subaluminous to strongly peraluminous $(\mathrm{A} / \mathrm{CNK}=$ 1.01-1.25). Major-element contents do not vary greatly but the trace elements show more significant differences between the granite varieties. From OG to LG, the rocks show decreasing overall REE abundances and La/Yb ratios.

Significant differences in Th and U concentrations occur between the marginal OG ( 49 ppm Th; 9 ppm U) and the more central IG ( $\sim 8 \mathrm{ppm}$ Th, $\sim 4 \mathrm{ppm} \mathrm{U}$ ). Hydrothermal thorite (found in the OG), xenotime and monazite are the main accessories concentrating these radioactive elements. The final stage of the magma evolution is represented by the central LG pulse containing beryl, wolframite and high-Li muscovite.

All pulses of the SCS are characterized by crust-like $\mathrm{Sr}-\mathrm{Nd}$ isotopic signatures. The inner IG shows more evolved $\mathrm{Sr}$ $\left({ }^{87} \mathrm{Sr}{ }^{86} \mathrm{Sr}_{326}=0.7098-0.7130\right)$ and less radiogenic $\mathrm{Nd}\left(\varepsilon_{\mathrm{Nd}} \mathrm{N}_{326}=-4.6\right.$ to -3.7$)$ than the outer $\mathrm{OG}\left({ }^{87} \mathrm{Sr}^{86} \mathrm{Sr}_{326}=0.7067-\right.$ $0.7076 ; \varepsilon \mathrm{Nd}_{326}=-2.5$ to -2.7$)$. The granite batches were probably derived by anatexis of Neoproterozoic or, more likely, Cambrian metagreywackes of the Teplá-Barrandian Unit. Enriched-mantle derived magmas (redwitzites) played a very important role as they not only provided the heat needed for the anatexis but also variably contributed material via magma mixing processes. The hybridization was particularly significant for the origin of the outer unit, which is rich in mafic microgranular enclaves and whose $\mathrm{Sr}$ is the least and Nd most radiogenic within the SCS.

Taken together, field observations, structural relations, U-Pb zircon dating, and geochemistry indicate that all pulses in the SCS were emplaced nearly simultaneously. However, each of them represented a single batch of magma with its own geochemical characteristics and petrogenetic features.

Keywords: nested pluton, highly fractionated granite, petrology, geochemistry, Teplá-Barrandian, Bohemian Massif

Received: 2 December 2019; accepted: 23 January 2020; handling editor: M. Kohút

The online version of this article (doi: 10.3190/jgeosci.294) contains supplementary electronic material

\section{Introduction}

Post-tectonic granitic magmatism along the southwestern edge of the amalgamated and exhuming Variscan Bohemian Massif (Fig. 1a-b) produced mainly S-type anatectic granite plutons but was also influenced by the strike-slip faulting and heating by the ascending mantlederived melts. It lasted from late Carboniferous to earliest Permian times (c. 330-320 Ma: Žák et al. 2014).

Finger et al. (2009), based on the compositional similarity of contemporaneous, voluminous granite types, proposed that the mid-Carboniferous Fichtelgebirge/Erzgebirge Batholith (Fig. 1; Saxothuringian Zone; Förster and Romer 2010) and the western branch of the South Bohemian Batholith (Moldanubian Zone; including the Oberpfalz and Bavarian Forest granite areas - Siebel et al. 2003) belonged to a single coherent and cogenetic, c. $400 \mathrm{~km}$ long plutonic megastructure, called the SaxoDanubian Granite Belt. This belt, discordant to the Devonian/Early Carboniferous collision-related tectonic architecture of the Bohemian Massif, could have formed in response to a post-collisional detachment of mantle lithosphere below the south-western sector of the Bohemian Massif (Finger et al. 2009).

The late Variscan granitoids of the NW Bohemian Massif (northeast Bavaria, west Bohemia), constitute six partly contiguous granitoid complexes: Fichtelgebirge, northern Oberpfalz, Waidhaus-Rozvadov, Bor, Karlovy Vary, and Babylon plutons, incorporating more than 20 intrusive units (Siebel et al. 1997). The Sedmihoří Composite Stock (SCS), a small shallow-level granite intrusion in the southwestern part of the Teplá-Barrandian 


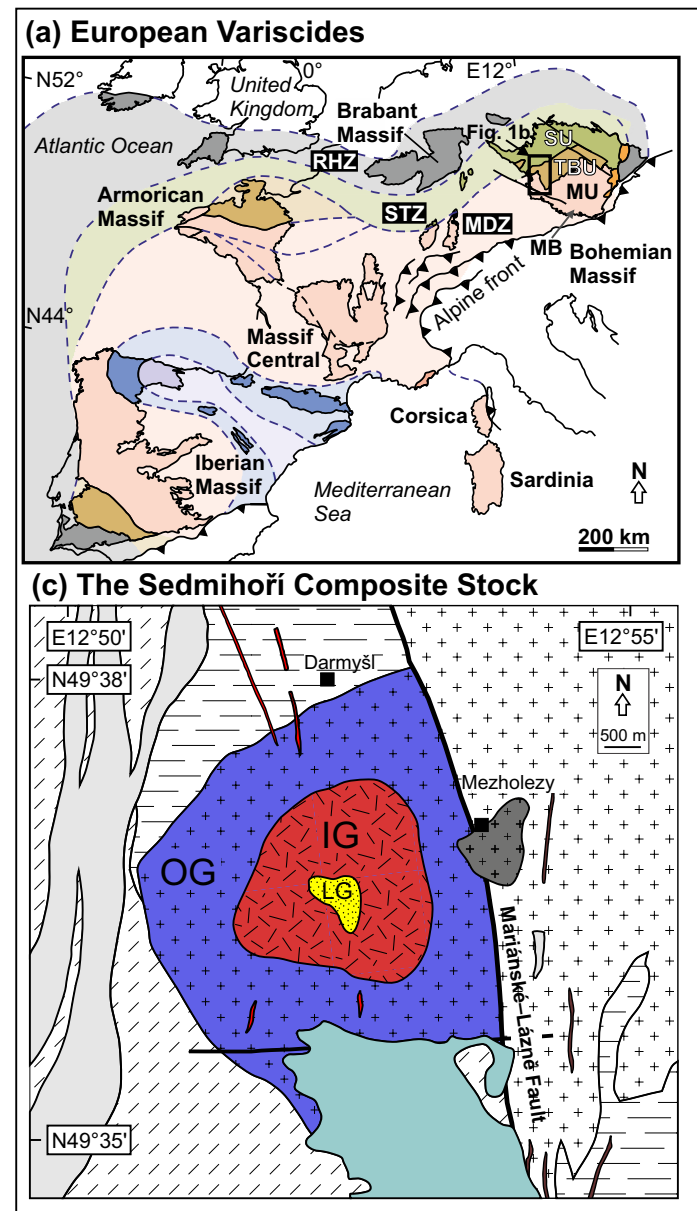

\section{(b) Western Bohemia}
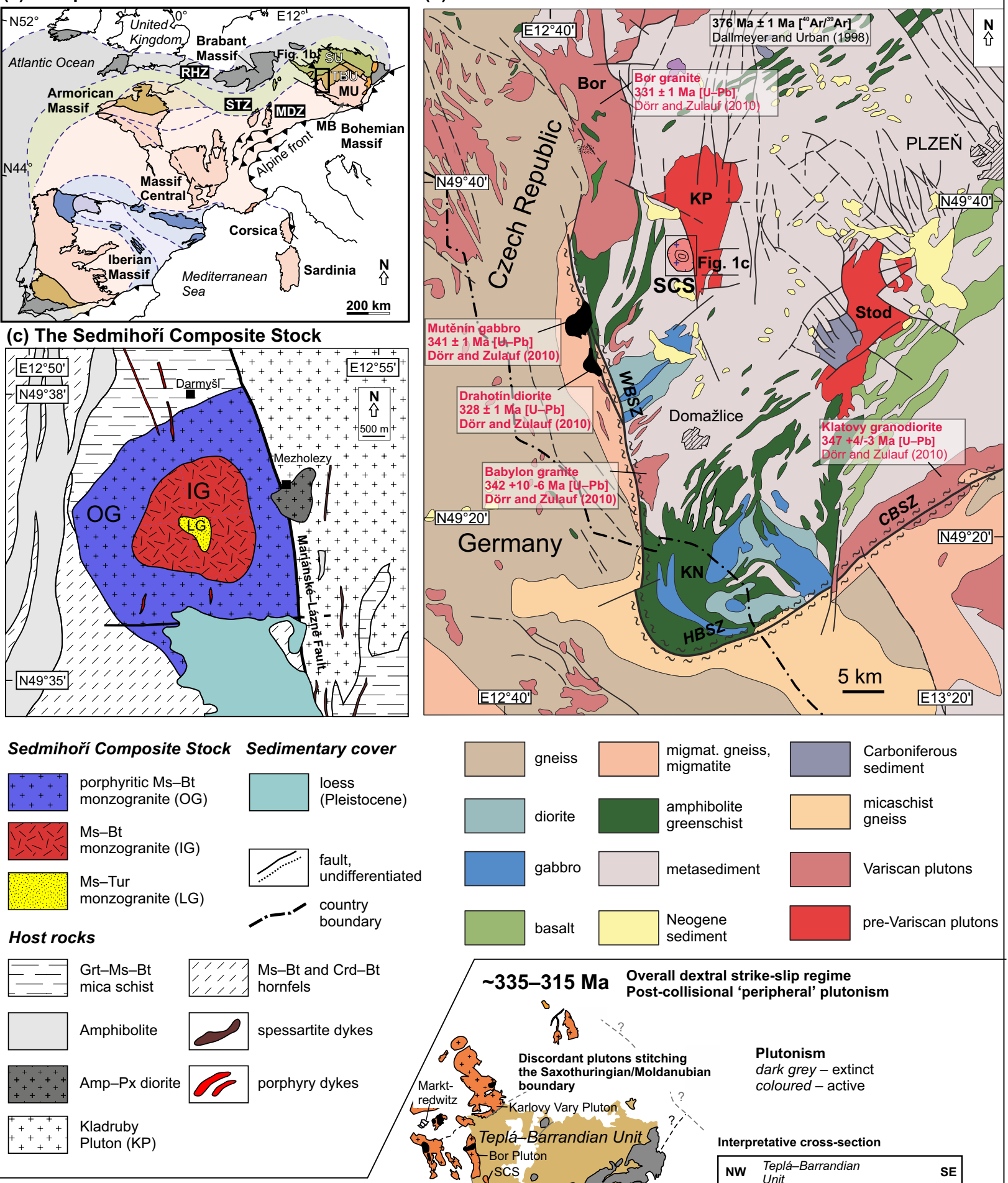

Late-orogenic (post-collisional) 'peripheral' granitoids Saxothuringian magmatic rocks

Various biotite and two-mica granites to

$[++$ granodiorites, commonly porphyritic, and

their eruptive/volcanic equivalents

redwitzites $\bigcirc$ diorites

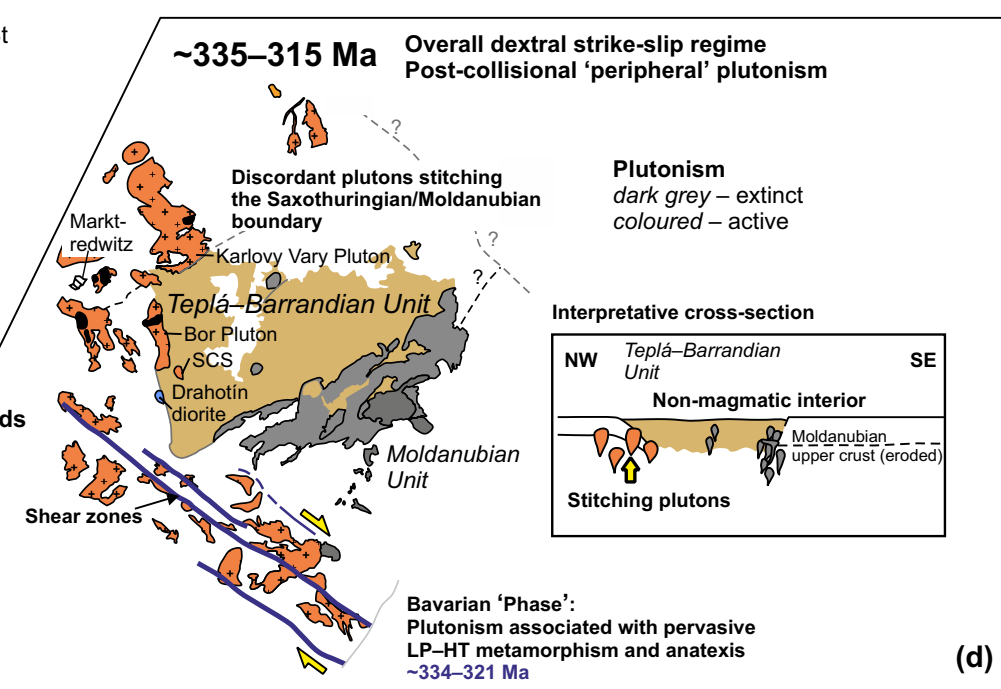


Unit, represents a nice example of this Late Variscan magmatic activity. The current study provides new petrographic, whole-rock geochemical, $\mathrm{Sr}-\mathrm{Nd}$ isotopic and $\mathrm{U}-\mathrm{Pb}$ geochronological data that constrain the nature, age and genesis of this interesting plutonic body. Our first aim was to establish the source of the parental magmas and to constrain their subsequent geochemical evolution. Moreover, the SCS, roughly circular in plan-view, represents an instructive case study of a nested post-tectonic granitic intrusion, emplaced as three magma pulses within a single conduit. Altogether, we shall demonstrate that the SCS is particularly suitable to address intriguing questions on how zoned plutons are constructed and for how long the upper crustal magma chambers remain active.

\section{Geological setting}

The study area is located along the contact zone between the Teplá-Barrandian Unit (TBU) and the Moldanubian Unit (MU) of the Bohemian Massif (Fig. 1a), close to the Bavaricum Domain (Fig. 1d).

\subsection{Teplá-Barrandian Unit}

The supracrustal Teplá-Barrandian Unit in the centre of the Bohemian Massif (Fig. 1b) is one of the bestpreserved segments of the Avalonian-Cadomian belt which developed along the northern active margin of Gondwana during the late Neoproterozoic to the earliest Cambrian (Nance et al. 2008, 2010 and references therein). The basement of the TBU is unique in that it exposes almost a complete section across the Cadomian active margin from a remnant meta-ophiolite complex to the NW, through an accretionary wedge, to a volcanic arc and intra-arc and back-arc basins to the SE (Hajná et al. 2012, 2013). The Teplá-Barrandian upper crust was intruded by several Late Devonian-early Carboniferous

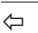

Fig. 1a - Map showing basement outcrop areas and principal lithotectonic zones of the Variscan orogenic belt in Europe. Bohemian Massif is the easternmost inlier of the orogen. Modified from Tomek et al. (2015). RHZ - Rhenohercynian Zone, STZ - Saxothuringian Zone, SU - Saxothuringian Unit, TBU - Teplá-Barrandian Unit, MDZ - Moldanubian Zone, MU - Moldanubian Unit. b - Geological map of the Western Bohemia (adopted and modified after Cháb et al. 2007 and Ackerman et al. 2010) with position of Variscan intrusions. WBSZ - Western Bohemian shear zone; HBSZ - Hoher Bogen shear zone; CBSZ - Central Bohemian shear zone. Plutons: SCS - Sedmihoří Composite Stock, KN - Kdyně-Neukirchen Massif, KP - Kladruby Pluton. c - Simplified geological map of the Sedmihoři Composite Stock and its host rocks. Redrafted from Czech Geological Survey map 1:50,000, sheet 21-21 Bělá nad Radbuzou. d - Greatly idealized sketch emphasizing spatial, temporal and compositional pattern of Variscan post-collisional magmatic rocks in the western part of the Bohemian Massif (adapted from Žák et al. 2014).
}

calc-alkaline granitoid plutons (Fig 1b). The existing U$\mathrm{Pb}$ and $\mathrm{Pb}-\mathrm{Pb}$ ages and structural relations of granitoid rocks associated with the West Bohemian Shear Zone (WBSZ; Zulauf 1994) indicate the initial stages of dextral shearing at c. 342-327 Ma and mylonitic deformation coeval with granite emplacement during c. 331-321 Ma (Chen and Siebel 2004; Siebel et al. 2005, 2006; Verner et al. 2009).

\subsection{Moldanubian Domain}

The Moldanubian Domain is interpreted as a root zone of the Variscan belt, resulting from the collision of Gondwana with Laurasia (e.g., Schulmann et al. 2009; Lardeaux et al. 2014). Metamorphic rocks of the Moldanubian Zone include mainly amphibolite-facies gneisses and migmatites with early Palaeozoic and late Proterozoic protolith ages (Košler et al. 2013), as well as highpressure granulites, often with lenses or larger bodies of garnet (Grt) and spinel (Spl) peridotites and eclogites (Vrána et al. 1995). Important is the presence of several voluminous Variscan granitoid plutonic complexes $(\mathrm{Zu}-$ lauf et al. 2002; Žák et al. 2014).

\subsection{Western contact of the Teplá-Barrandian and Moldanubian units}

The southwestern contact between the TBU and the MU is formed by the West Bohemian Shear Zone, indicating late Variscan orogen-parallel (WSW-ENE) extension within the Variscan internides. Along the WBSZ, the western part of the TBU was downthrown to the east against the adjacent MU. According to seismic data, the steeply east-dipping WBSZ flattens with depth, forming a prominent detachment zone. Cross-cutting relationships of WBSZ mylonites and Carboniferous granites, as well as the available cooling ages of hornblende and mica, suggest that ductile normal faulting along the WBSZ was active from c. 330 to $310 \mathrm{Ma}$ (Zulauf 1994).

\subsection{Sedmihoří Composite Stock}

The Sedmihoří Composite Stock (SCS) is a post-tectonic, shallow-level intrusion (the depth of magma solidification was $\sim 2.5 \mathrm{~km}$; Dudek et al. 1957) that intruded into the southwestern part of the Domažlice Crystalline Complex, Teplá-Barrandian Unit, close to the West Bohemian Shear Zone (WBSZ in Fig. 1b). The SCS was investigated by Vejnar (1967, 1984), Ali-Bik (1996) and Voves et al. (1997). These studies have summarized the basic petrological characteristics but more modern geochemical and geochronological studies (other than $\mathrm{Rb}-\mathrm{Sr}$ ) are lacking. 
In map view, the SCS has a roughly circular outline with dimensions of $8 \times 10 \mathrm{~km}\left(\sim 15 \mathrm{~km}^{2}\right.$; Fig. 1c) and is formed by three granitic units: (i) outer porphyritic biotite monzogranite (OG; $\left.11 \mathrm{~km}^{2}\right)$, (ii) inner biotite-muscovite monzogranite (IG; $3.8 \mathrm{~km}^{2}$ ), and (iii) the innermost small body of fine-grained muscovite leucogranite with tourmaline $\left(\mathrm{LG} ; 0.3 \mathrm{~km}^{2}\right)$. The boundaries between individual units are fairly sharp. In the northern and southern parts, the SCS hosts numerous late-stage pegmatite and aplite dykes $5-10 \mathrm{~cm}$ wide and poorly exposed, NNW-SSE trending granite porphyry dykes (a few centimetres thin).

The northwestern margin of the pluton is in contact with the high-grade Neoproterozoic (Ediacaran) micaschists of the Teplá-Barrandian Unit (e.g., Neužilová and Vejnar 1966). The southern margin of SCS is rimmed by hornfels but largely concealed beneath Pleistocene loess. The eastern contact of the pluton with the Mezholezy diorite and Cambro-Ordovician Kladruby Pluton is probably intrusive. The SCS and Kladruby Pluton are separated from each other by the NNW-SSE system of the Mariánské Lázně Fault that is older than the intrusion of the SCS (Fig. 1c; Neužilová and Vejnar 1966).

\section{Methods}

\subsection{Electron-microprobe (EMP) analyses and BSE imaging}

Analyses of the major rock-forming and selected accessory minerals were done with a fully automated CAMECA SX-100 electron microprobe, employing $\Phi(\rho z)$ correction procedure (Merlet 1992) in the Joint Laboratory of the Faculty of Natural Sciences of the Masaryk University and the Czech Geological Survey in Brno (operator P. Gadas). All analyses were performed at an acceleration voltage of $15 \mathrm{kV}$. For feldspars, micas and quartz, the beam current was 10-15 nA and spot size $2 \mu \mathrm{m}$. Currents of 20-40 nA and a spot sizes of 5-10 $\mu \mathrm{m}$ were employed for apatite, titanite, rutile, monazite, magnetite, ilmenite, and thorite. Interferences have been checked routinely and corrected by measuring the corresponding standards. The mineral abbreviations used are after Whitney and Evans (2010).

\subsection{U-Pb LA ICP-MS dating}

Zircons were concentrated from the $60-125 \mu \mathrm{m}$ fraction by combined Wilfley shaking table, magnetic and heavy liquid (tetrabrommethan) separation. The zircons and monazites were finally handpicked, mounted in epoxy resin and polished. Prior to analyses, all zircon grains were characterized by scanning electron microscope (SEM) with cathodoluminescence (CL) imaging at
Institute of Petrology and Structural Geology, Charles University in Prague.

Uranium and lead isotope analyses were carried out by laser ablation - inductively coupled plasma - mass spectrometry (LA-ICP-MS) at the Goethe University of Frankfurt (GUF), using a slightly modified method of Gerdes and Zeh $(2006,2009)$ and Zeh and Gerdes (2012). A ThermoScientific Element 2 sector field ICP-MS was coupled to a Resolution M-50 (Resonetics) $193 \mathrm{~nm} \mathrm{ArF}$ Excimer laser (CompexPro 102, Coherent) equipped with two-volume ablation cell (Laurin Technic, Australia). The laser was fired with $5.5 \mathrm{~Hz}$ repetition rate at a fluence of c. $2 \mathrm{~J} \mathrm{~cm}^{-2}$. This configuration at a spot size of $26 \mu \mathrm{m}$ and depth of penetration of $0.6 \mu \mathrm{m} \mathrm{s}^{-1}$ yielded a sensitivity of $10000-13000 \mathrm{cps} / \mu \mathrm{g}$ for ${ }^{238} \mathrm{U}$. Raw data were corrected offline for background signal, common $\mathrm{Pb}$, laser-induced elemental fractionation, instrumental mass discrimination, and time-dependent elemental fractionation of $\mathrm{Pb} / \mathrm{U}$ using an in-house MS Excel ${ }^{\circ}$ spreadsheet program (Gerdes and Zeh 2006, 2009). Laser-induced elemental fractionation and instrumental mass discrimination were corrected by normalization to the reference zircon GJ-1 $(0.0984 \pm 0.0003$; ID-TIMS GUF value). Repeated analyses of the 91500 (Wiedenbeck et al. 1995), Plešovice (Sláma et al. 2008) and Felix (Millonig et al. 2012) reference zircons during the same analytical session yielded an accuracy better than $1 \%$ and a reproducibility of $<2 \%(2 \sigma)$. All uncertainties are reported at the $2 \sigma$ level. The data were plotted using the ISOPLOT software (Ludwig 2003).

\subsection{Whole-rock geochemical analyses}

Large (c.15-30 kg) and fresh samples were taken from outcrops and from one abandoned quarry for whole-rock geochemical studies. Samples were crushed at the Czech Geological Survey, Prague-Barrandov (CGS) to 2-4 cm grain-size using a steel jaw crusher, homogenized and split to $500-1500$ g. Finally, aliquots of $c .300$ g were pulverized in an agate mill.

The whole-rock major-element analyses were carried out by wet chemistry in the CGS laboratories. The relative $2 \sigma$ uncertainties were better than $1 \%\left(\mathrm{SiO}_{2}\right), 2 \%$ $(\mathrm{FeO}), 5 \%\left(\mathrm{Al}_{2} \mathrm{O}_{3}, \mathrm{~K}_{2} \mathrm{O}, \mathrm{Na}_{2} \mathrm{O}\right), 7 \%\left(\mathrm{TiO}_{2}, \mathrm{MnO}, \mathrm{CaO}\right)$, $6 \%(\mathrm{MgO})$ and $10 \%\left(\mathrm{Fe}_{2} \mathrm{O}_{3}, \mathrm{P}_{2} \mathrm{O}_{5}\right)$ (Dempírová 2010).

The trace-element abundances were obtained in the Activation Laboratories Ltd. (Ancaster-Canada) with the 4B2-research method. The samples were analysed by ICP-OES following a lithium metaborate or tetraborate fusion and dilute nitric digestion of a $0.2 \mathrm{~g}$ sample. The REE and refractory metals were determined by ICP-MS following a lithium metaborate or tetraborate fusion and nitric acid digestion of a $0.2 \mathrm{~g}$ sample. For further analytical details, see http://www.actlabs.com. 
Whole-rock geochemical data were interpreted and plotted using the freeware R-language package GCDkit, version 3.0 (Janoušek et al. 2006, 2011; www.gcdkit.org).

\subsection{Radiogenic isotopes}

For the radiogenic isotope determinations, samples were dissolved using a combined $\mathrm{HF}-\mathrm{HCl}-\mathrm{HNO}_{3}$ attack. Strontium and bulk REE were isolated from the matrix using PP columns filled with Sr.spec and TRU.spec Eichrom resins (Pin et al. 1994). The Nd was further separated from the REE fraction on PP columns with Ln.spec Eichrom resin (Pin and Zalduegui 1997). Further analytical details were reported by Míková and Denková (2007). Isotopic analyses of Sr and Nd were performed on a Finnigan MAT 262 thermal ionization mass spectrometer housed at the CGS in dynamic mode using a single $\mathrm{Ta}$ filament for $\mathrm{Sr}$ and double Re filament assembly for $\mathrm{Nd}$. The ${ }^{143} \mathrm{Nd} /{ }^{144} \mathrm{Nd}$ ratios were corrected for mass fractionation to ${ }^{146} \mathrm{Nd} /{ }^{144} \mathrm{Nd}=$ 0.7219 (Wasserburg et al. 1981), ${ }^{87} \mathrm{Sr} /{ }^{86} \mathrm{Sr}$ ratios assuming ${ }^{86} \mathrm{Sr} r{ }^{88} \mathrm{Sr}=0.1194$. External reproducibility is estimated from repeat analyses of the JNdil (Tanaka et al. 2000) $\left[{ }^{143} \mathrm{Nd} /{ }^{144} \mathrm{Nd}=0.512101 \pm 14(2 \sigma, \mathrm{n}=10)\right]$ and NBS 987 $\left[{ }^{87} \mathrm{Sr} r{ }^{86} \mathrm{Sr}=0.710247 \pm 26(2 \sigma, \mathrm{n}=22)\right]$ isotope standards. The decay constants applied to age-correct the isotopic ratios are from Steiger and Jäger $(1977$ - Sr) and Lugmair and Marti $(1978-\mathrm{Nd})$. The $\varepsilon_{\mathrm{Nd}}$ values were obtained using Bulk Earth parameters of Jacobsen and Wasserburg (1980), the two-stage Depleted Mantle Nd model ages $\left(\mathrm{T}_{\mathrm{DM}}^{\mathrm{Nd}}\right)$ were calculated after Liew and Hofmann (1988).

\section{Results}

\subsection{Petrology}

A detailed summary of the previously published (Vejnar 1984) and new data concerning the field relationships, petrography and mineral chemistry of the three main lithologies distinguished within the SCS are given below. At the macro and micro-scale, the textures are exclusively magmatic, Bt and Fsp grains have euhedral to subhedral shapes and interstitial Qtz is not recrystallized. Crystals of the main rock-forming minerals exhibit no effects of solid-state deformation.

\subsubsection{Outer porphyritic biotite monzogranite (OG)}

The OG is a light grey rock with abundant white K-feldspar phenocrysts, $0.5-3 \mathrm{~cm}$ across (Fig. 2a-b). K-feldspar phenocrysts account for $<50 \%$ of the volume. In general, the main mineral assemblage is (in vol. \%): quartz
(26-37), K-feldspar (30-44), plagioclase (23-33), biotite $(4-7)$ and traces of muscovite $(<1)$, with accessory zircon, monazite, thorite, xenotime-(Y), apatite, ilmenite, rutile, magnetite and synchysite-(Ce). The texture is hypidiomorphic (Fig. 2c).

The OG hosts frequent mafic microgranular enclaves (MME; Barbarin and Didier 1992) with average size of c. 15-20 cm and circular shapes (Fig. 2a). These MME make up less than 1 vol. \% of the OG units and often enclose K-feldspar xenocrysts. In addition, restite biotite enclaves were identified and contain K-feldspar $(2-3 \mathrm{~cm}$ in size). Rare angular metasedimentary xenoliths (15-20 $\mathrm{cm}$ across) locally occur.

\subsubsection{Inner biotite-muscovite monzogranite (IG)}

The IG unit is formed by sparsely porphyritic, whitish to ochre-grey, medium- to coarse-grained biotite-muscovite granite. The rock is isotropic with a hypidiomorphic texture (Fig. 2d). Typical assemblage is (in vol. \%): quartz (30-38), plagioclase (29-32), K-feldspar (24-30), muscovite (5-8) and biotite (1-3). Accessories are represented by zircon, monazite, apatite, xenotime, sphene, ilmenite, rutile, andalusite, beryl and wagnerite. Quartz has a teardrop shape.

Rare metasedimentary xenoliths reach up to $7 \times 25$ $\mathrm{cm}$; the MME are absent. A further main difference from the OG is the presence of primary(?) muscovite. The IG granites weather more easily than OG, resulting in a morphologically conspicuous inner depression around the Sedmihoří ring.

\subsubsection{Tourmaline-muscovite leucogranite (LG)}

This rock, building the centre of the SCS, is fine-grained, whitish-grey, and contains small, up to $1 \mathrm{~cm}$ long $\mathrm{K}$-feldspar phenocrysts. The mineral assemblage is (in vol. \%): quartz (32-43), plagioclase (33-37), K-feldspar (17-22), muscovite (7), tourmaline (2) and biotite (1). Accessories are represented by zircon, monazite, apatite, ilmenite, rutile, and wolframite. The texture is hypidiomorphic (Fig. 2e). The tourmaline forms black crystals and needles $(0.2-4 \mathrm{~mm})$. Characteristic are variously scattered miarolitic cavities. This granite is more durable than the IG, and therefore forms a striking elevation in the centre of the SCS structure.

\subsection{Mineralogy and mineral chemistry}

The SCS is a composite body, whereby the original mineral assemblages in each of its magmatic units reflect the 

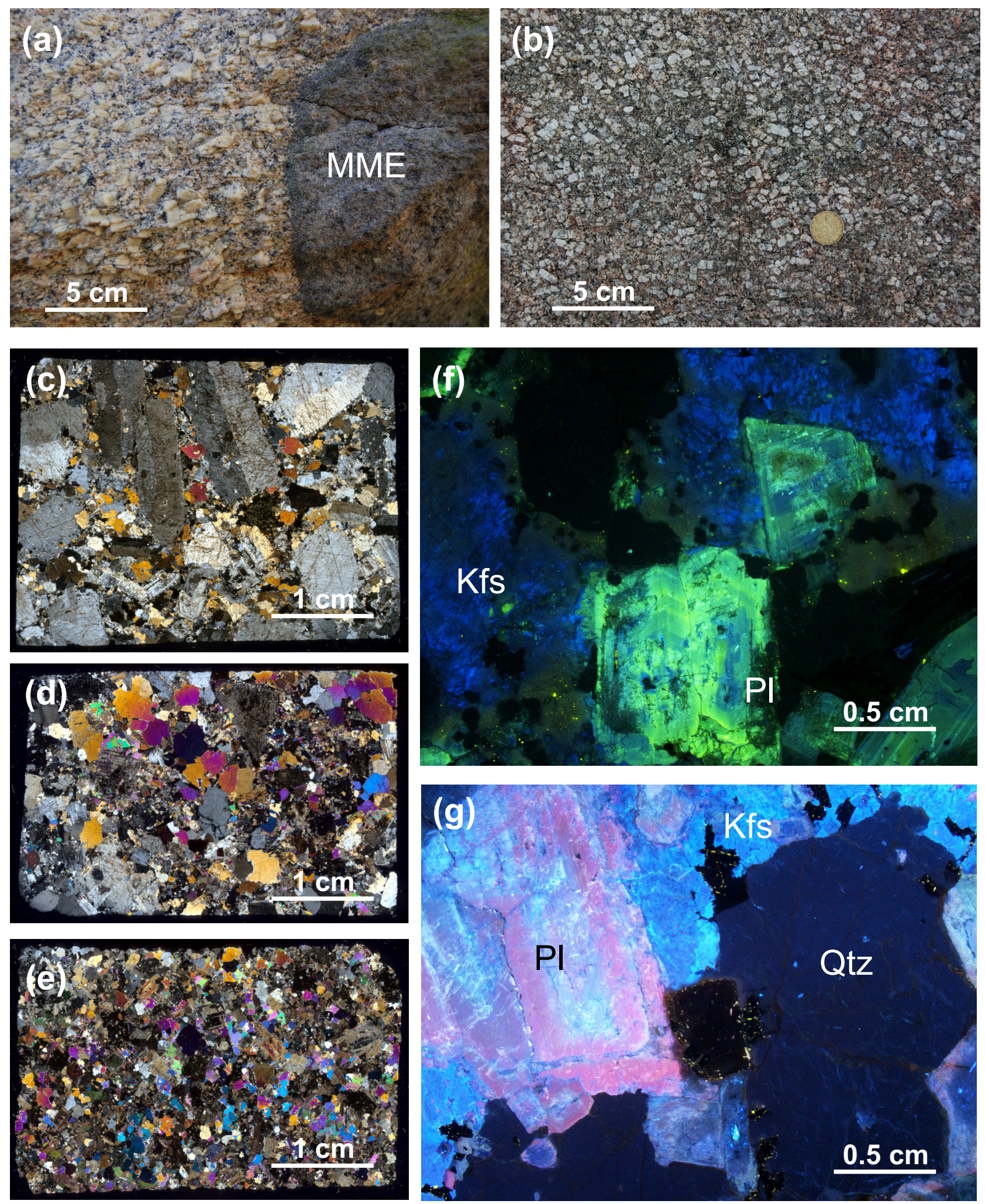

Fig. 2 Field photographs. a - Mafic microgranular enclave (MME) in the porphyritic granite OG (outcrop SH3 [49.62907978 N; 12.86889117 E]). K-feldspar phenocrysts in the granite lacking any evidence of solid-state deformation; b - Detail of magmatic foliation defined by Kfs (outcrop SH6 [49.60663732 N; 12.86929552 E]). Granite textures of the three main units of the SCS (scanned polished sections, crossed polars). c-Outer granite unit (OG) with Kfs phenocrysts; d - Inner granite unit (IG) with equigranular texture of Kfs, Qtz and micas; e - Leucogranite unit (LG) with fine-grained texture of $\mathrm{Kfs}$, Qtz, micas and tourmaline. Optical cathodoluminescence images $(C L)$. f-Oscillatory-zoned plagioclase with greenish yellow and unzoned K-feldspar with blue emission. $\mathbf{g}$ - Non-luminescent quartz, blue K-feldspar and plagioclase with red cathodoluminescence due to elevated $\mathrm{Fe}^{3+}$ content. 
evolution of magma from the margin to the centre of the stock. Below are briefly reported the main features and the mineral chemistry of major rock-forming and accessory minerals (see Supplementary material $\mathbf{1}$ for full analytical set).

\subsubsection{Major rock-forming minerals}

Quartz occurs as light grey anhedral crystals, up to $2 \mathrm{~mm}$ across, often forming aggregates with sharp boundaries in all the magmatic units.

Perthitic K-feldspar commonly shows cross-hatched or Carlsbad twinning. Euhedral phenocrysts $(0.5-3 \mathrm{~cm})$ are sharply separated from the matrix. In contrast, the $\mathrm{K}$-feldspar crystals in the matrix are much smaller $(0.5-2$ $\mathrm{mm})$ and anhedral. The phenocrysts enclose small $(<0.5$ $\mathrm{mm}$ ) subhedral laths of sodic plagioclase, overgrown by thin albite rims. Minor inclusions of biotite, plagioclase, quartz and accessories (e.g., apatite and zircon) are abundant and usually enclosed in the central parts of the K-feldspar phenocrysts.

The K-feldspars are not compositionally uniform across the pluton (OG: $\mathrm{Or}_{85-94}$; IG: $\mathrm{Or}_{90-98}$; LG: $\mathrm{Or}_{97-98}$ ). The $\mathrm{P}_{2} \mathrm{O}_{5}$ concentrations in the OG are often close to the detection limit (0.004-0.081 wt. \%), while they are elevated in IG and LG (IG: 0.003-0.285 wt. \%; LG: $0.054-0.159$ wt. \%).

Plagioclase forms mostly subhedral grains, on average 0.5-2 mm across, with common albite law twin lamellae and inclusions of biotite and quartz. The rim of plagioclase is albite to oligoclase (OG: $\mathrm{An}_{0.6-14}$; IG: $\mathrm{An}_{0.5-5}$; LG: $\left.\mathrm{An}_{0.2-0.5}\right)$. Cores are slightly normally zoned and some are mantled by sodic plagioclase (OG: $\mathrm{An}_{11-36}$; IG: $\mathrm{An}_{10-33}$ ). The LG is characterized by strong albitization $\left(\mathrm{An}_{0.7-2}\right)$. Besides the common yellow-green (Fig. 2f), also red cathodoluminescence was observed in plagioclase from the OG (Fig. 2g). This is probably triggered by $\mathrm{Fe}^{3+}$ that occupies $\mathrm{Al}^{3+}$ tetrahedral sites in the feldspar (Smith and Stenstrom 1965; Geake et al. 1977).

Biotite occurs as subhedral to euhedral flakes 0.5-1.5 $\mathrm{mm}$ across. Zircon, apatite, and titanite are closely associated with biotite. Biotite in the $\mathrm{OG}$ is classified as annite with $12.9-14$ wt. $\% \mathrm{Al}_{2} \mathrm{O}_{3}$ and $3.7-4.0$ wt. $\% \mathrm{MgO}$. The biotite from the IG and LG is siderophyllite with fe\# (molar $\mathrm{FeO}_{t} /\left[\mathrm{MgO}+\mathrm{FeO}_{t}\right]$ ) of $0.7-0.8$ and $0.8-0.9$. The $\mathrm{MnO}$ contents in the OG are lower $(0.49-0.57$ wt. \%) than in IG and LG (0.67-1.38 wt. \%; 0.90-1.18 wt. \%); the $\mathrm{K}_{2} \mathrm{O}$ abundances increase inwards in the stock (from $8.0-9.3$ to $9.2-9.8$ wt. \%). Biotites in the marginal OG contain on average more $\mathrm{TiO}_{2}(2.6-3.6$ wt. \%) than those in the central LG (0.9-2.1 wt. \%). There is also a trend of increasing $\mathrm{F}$ and $\mathrm{LiO}_{2}$ (calculated) in biotite from the stock margin $\left(0.5-1.6\right.$ wt. $\% \mathrm{~F} ; 0.4-0.8$ wt. $\left.\% \mathrm{LiO}_{2}\right)$ to the centre (3.3-4.5 wt. \% F; $1.6-2.3$ wt. $\left.\% \mathrm{LiO}_{2}\right)$.
Muscovite occurs in flakes $(\sim 0.6 \mathrm{~mm})$ with biotite and is common in the IG and the LG units. It is classified as aluminoceladonite based on $\mathrm{SiO}_{2}$ (IG: 45.4-48.4 wt. \%; LG: 44.4-46.8) and total $\mathrm{Al}_{2} \mathrm{O}_{3}$ (IG: 28.6-34.7 wt. \%; LG: $29.5-35.0 \mathrm{wt}$ \%). The muscovite is characterized by $\mathrm{F}$ and $\mathrm{LiO}_{2}$ contents increasing from IG $(0.9-2.1 \mathrm{wt} . \%$ $\mathrm{F}$ and $0.2-0.6$ wt. $\left.\% \mathrm{LiO}_{2}\right)$ to $\mathrm{LG}(1.3-3.1$ wt. $\% \mathrm{~F}$ and $0.3-0.9$ wt. $\% \mathrm{LiO}_{2}$ ).

\subsubsection{Accessory minerals}

Fluorapatite prisms $(0.1-0.2 \mathrm{~mm})$ or needles with a homogeneously high content of fluorine (OG: 2.2-2.7, IG: 2.1-2.8, LG: 2.3-2.9 apfu) are abundant in all rock types of the SCS.

Less common is monazite in aggregates of small spherical crystals $(0.2 \mathrm{~mm})$. They are fresh, compact with sector or oscillatory zoning. The monazites always host high $\mathrm{ThO}_{2}$ (OG: 3.9 wt. \%; IG: 4.7-9.2 wt. \%; LG: $3.9-10.2$ wt. \%) and moderate $\mathrm{UO}_{2}$ concentrations (OG: 0.2 wt. \%; IG: $0.07-1.18$ wt. \%; LG: 0.3-0.7 wt. \%).

Euhedral zircon $(0.2 \mathrm{~mm})$ occurs in all magmatic units as pink to pale brown, short-prismatic (dipyramidal) crystals. Zircons are poor in $\mathrm{U}$ and $\mathrm{Th}$ and contain $\mathrm{HfO}_{2}$ concentrations as follows, OG: $1.06-1.92$ wt. \%; IG: 1.07-1.45 wt. \%; LG: $1.45-2.02$ wt. \%.

Subangular thorite (up to $0.1 \mathrm{~mm}$ across) is restricted to the OG unit, which is Th-U and HREE-rich. It occurs in plagioclase, often together with monazite. Due to relatively high Th contents, crystals are metamict and altered. The analyzed phase appears to be an end-member of the zircon-thorite solid solution series $(0.66-0.88$ apfu Th, 0.001-0.002 apfu Zr). The crystals show low amounts of $\mathrm{FeO}_{\mathrm{t}}(1.46-3.30$ wt. \%). The phase is highly enriched in $\mathrm{Ca}$ and $\mathrm{F}(0.45-1.99$ wt. \% $\mathrm{CaO} ; 1.39-1.73$ wt. \% F).

Few altered euhedral xenotime-(Y) inclusions $(<0.05$ $\mathrm{mm}$ ) were found in monazite of the OG and IG units. Their composition is characterized by variably elevated $\mathrm{ThO}_{2}$ (OG: 1.3 wt. \%; IG: 0.3 wt. \%), UO $\mathrm{UO}_{2}$ (OG: 1.2 wt. \%; IG: 2.3-3.2 wt. \%), as well as HREE. Zirconium content is low (OG: 0.5 wt. \% $\mathrm{ZrO}_{2}$; IG: 0.6 wt. $\% \mathrm{ZrO}_{2}$ ).

Ilmenite in all magmatic units forms black opaque grains $(0.1 \mathrm{~mm})$, in cases lamellated. The most significant substitution is the $\mathrm{Fe}-\mathrm{Mn}$ replacement. In the $\mathrm{OG}$ and LG units, MnO contents are relatively low (OG: 6.3-7.7, LG: 4.8 wt. \%), but in the IG they increase significantly (5.5-25.0 wt. \%); therefore, this phase can be classified as pyrophanite.

Euhedral rutile-(Nb, Ta) grains $(0.1 \mathrm{~mm})$ are relatively common and are chemically unzoned except for rare clear patches enriched in $\mathrm{Fe}$. Rutiles in the OG are relatively $\mathrm{Nb}$, Ta-poor ( $<0.5$ wt. $\% \mathrm{Nb}_{2} \mathrm{O}_{5} ;<0.008$ wt. $\% \mathrm{Ta}_{2} \mathrm{O}_{5}$ ). In contrast, the IG and LG rutiles show high contents of $\mathrm{Nb}$ and Ta (IG: $0.7-5.0$ wt. $\% \mathrm{Nb}_{2} \mathrm{O}_{5}$; 0.04-0.5 wt. $\% \mathrm{Ta}_{2} \mathrm{O}_{5}$; 
LG: $2.1-3.7$ wt. $\% \mathrm{Nb}_{2} \mathrm{O}_{5}$ and $0.1-0.2$ wt. $\% \mathrm{Ta}_{2} \mathrm{O}_{5}$ ). One analysis yielded high contents of $\mathrm{Nb}$ and $\mathrm{Ta}(40.3 \mathrm{wt}$. \% $\mathrm{Nb}_{2} \mathrm{O}_{5}$ and 14.5 wt. $\% \mathrm{Ta}_{2} \mathrm{O}_{5}$ ) and probably represents a mineral from the columbite family.

Black magnetite grains were found in the OG only. Magnetite occurs mostly as anhedral fragments, only rarely forming octahedra, up to $0.5 \mathrm{~mm}$ across. Contents of $\mathrm{MnO}$ are low (0.031-0.045 wt. \%) but $\mathrm{TiO}_{2}$ is elevated $(0.1-0.3$ wt. \%). Titanite occurs solely in the IG as brown to reddish euhedral crystals $(0.1 \mathrm{~mm})$. The grains show sector zoning in BSE images. They contain high $\mathrm{F}$ (0.8-1.4 wt. \%) and are rich in $\mathrm{Sn}\left(2.3-4.3\right.$ wt. $\left.\% \mathrm{SnO}_{2}\right)$.

In the LG, numerous subhedral grains of tourmaline were observed (up to $1 \mathrm{~mm}$ ) with optical zoning (ochre rim-green core). Tourmalines correspond to schorl to fluor-elbaite with high $\mathrm{Ca}(0.1-0.2 \mathrm{apfu})$ and Li contents (0.3-0.6 apfu).

Black coarse-grained prismatic crystals of wolframite were found in the LG that contain $44-45 \mathrm{~mol}$. \% ferberite and 53-54 mol. \% hübnerite. High content of $\mathrm{Nb}$ was observed in wolframite grains (2.6-2.9 wt. \% $\mathrm{Nb}_{2} \mathrm{O}_{5}$ ).

Beryl was only noted in the IG, where it forms secondary solitary euhedral grains, up to 50-100 $\mu \mathrm{m}$ long, frequently arranged in/around skeletal aggregates of cordierite.

Primary andalusite from the IG is enclosed in the muscovite aggregates and shows slightly elevated $\mathrm{Fe}$ $\left(0.1-0.3\right.$ wt. $\left.\% \mathrm{FeO}_{\mathrm{t}}\right)$ and is nearly homogeneous in composition.

Secondary wagnerite occurs only in the IG in muscovite and represents isomorphic series between $(\mathrm{Mg}$, $\mathrm{Mn})$ and Fe-rich grains. The phases have homogeneous composition, except enrichment in $\mathrm{Ca}(0.8$ wt. \% $\mathrm{CaO})$.

\subsection{U-Pb zircon geochronology}

In order to constrain the intrusive age for of the main pulses within the SCS zircons of a porphyritic Bt monzogranite (OG, sample SH3; WGS84 coordinates: $\mathrm{N} 49.629080^{\circ}, \mathrm{E} 12.868891^{\circ}$ ) and a Bt-Ms monzogranite (IG, sample SH12; WGS84 N 49.621257º, E $12.872292^{\circ}$ ) were analysed by the LA ICP-MS method (see Supplementary Material 2 for the complete data set).

The zircons from the OG are subhedral to euhedral, short prismatic, with severely suppressed pyramids. Typical length ranges between 100 and $250 \mu \mathrm{m}$. Their CL images reveal magmatic oscillatory zoning as well as the presence of apatite inclusions without any preferred orientation (Fig 3a). Other grains tend to be uniformly dark or patchily zoned in CL.

In the $\mathrm{OG}$ and $\mathrm{IG}$, euhedral prismatic zircon grains of typical length $100-250 \mu \mathrm{m}$ are characterized by more conspicuous pyramid faces. Again, they show clearly magmatic oscillatory zoning with bright cores (Fig. 3b). Inherited cores are rarer than in the OG.
The Variscan $\mathrm{U}-\mathrm{Pb}$ data for the zircon grains from each sample are summarized in the concordia plots (Fig. 3c-d). The statistically indistinguishable concordia ages of $326.2 \pm 1.2 \mathrm{Ma}(2 \sigma)(\mathrm{SH} 3(\mathrm{OG})-\mathrm{n}=28$, MSWD $=1.2)$ and $326.5 \pm 1.2 \mathrm{Ma}(\mathrm{SH} 12(\mathrm{IG})-\mathrm{n}=34, \mathrm{MSWD}=$ $1.2)$ are interpreted as magma emplacement ages.

\subsection{Whole-rock geochemistry}

\subsubsection{Major elements}

The dataset includes fourteen newly obtained samples from the main varieties of the SCS (see Tab. 1 for complete major-element data set, including sample locations) and twelve analyses from the literature (Vejnar 1967, 1984; Ali-Bik 1996; Voves et al. 1997).

The three main SCS units are all silica-rich $\left(\mathrm{SiO}_{2}=\right.$ OG: 71.63-72.96 wt. \%; IG: 73.24-74.21 wt. \%; LG: 73.28-74.11 wt. \%). This is indicated also by the Q'ANOR classification diagram (Streckeisen 1979; Fig. 4a) where the OG corresponds to syenogranites, and IG with LG to alkali feldspar granites. The B-A plot (Debon and Le Fort 1983; Fig. 4b) is used to express the contents of mafic components $\mathrm{Fe}, \mathrm{Mg}$ and $\mathrm{Ti}(=\mathrm{B})$, their relation to the aluminium balance $(=\mathrm{A})$ and thus the characteristic mineral assemblage (Bonin et al. in print). All the rock types are subaluminous to strongly peraluminous, as shown by $\mathrm{A} / \mathrm{CNK}$ values $(\mathrm{A} / \mathrm{CNK}=$ $\mathrm{Al}_{2} \mathrm{O}_{3} /\left(\mathrm{CaO}+\mathrm{Na}_{2} \mathrm{O}+\mathrm{K}_{2} \mathrm{O}\right)$ in mol. \%; Shand 1943) of 1.01-1.27 (broadly increasing from $\mathrm{OG}$ to $\mathrm{IG}+\mathrm{LG}$ ). The modification of the same diagram by Villaseca et al. (1998) shows that the samples form a data array from low peraluminous to felsic peraluminous domains (Fig. 4c). Samples of OG unit are mostly shoshonitic; IG and LG can be characterized as mostly high-K calcalkaline rocks in the $\mathrm{SiO}_{2}-\mathrm{K}_{2} \mathrm{O}$ diagram (Peccerillo and Taylor 1976; Fig. 4d).

In general, the major-element compositions show significant differences between the three granite units. Binary diagrams display poor negative linear correlations of $\mathrm{SiO}_{2}$ with $\mathrm{TiO}_{2}, \mathrm{FeO}_{\mathrm{t}}$ and $\mathrm{CaO}$ (Fig. 5). The $\mathrm{P}_{2} \mathrm{O}_{5}$ content increases from the margin (OG; 0.051-0.140 wt. \%) to the centre (IG $+\mathrm{LG} ; 0.20-0.36$ wt. \%).

\subsubsection{Trace elements}

If compared with the upper continental crustal composition (UCC: Taylor and McLennan 1995; Fig. 6a), all the three main units are enriched in Large-Ion Lithophile Elements (LILE; $\mathrm{Cs}, \mathrm{Rb}, \mathrm{K}$ ), and depleted in $\mathrm{Ba}, \mathrm{Sr}$ and some High Field Strength Elements (HFSE; Nb, Ti, and $\mathrm{U})$. The outer, OG unit shows markedly lower $\mathrm{Cs}, \mathrm{Rb}$ and $\mathrm{P}$ contents at elevated $\mathrm{Th}, \mathrm{Hf}, \mathrm{Zr}$ and all REE than the inner and innermost units (see also Tab. 2). 
(a)
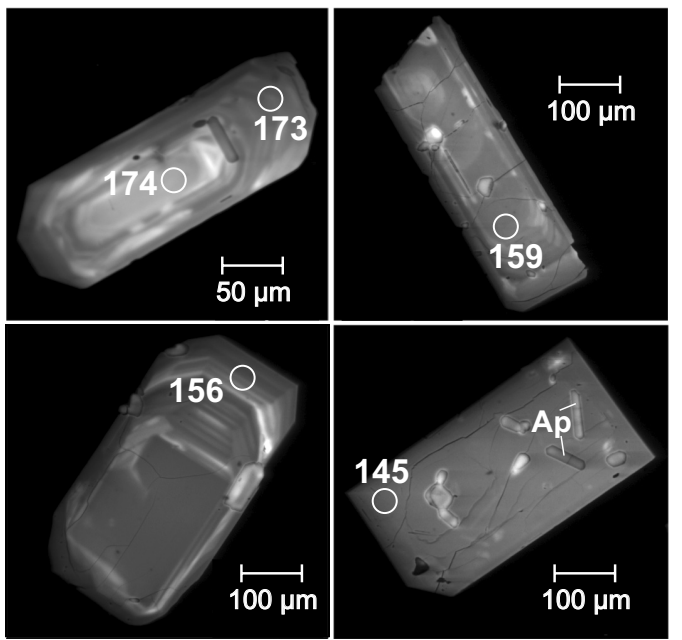

Kfs-phyric Bt monzogranite (OG)

(b)

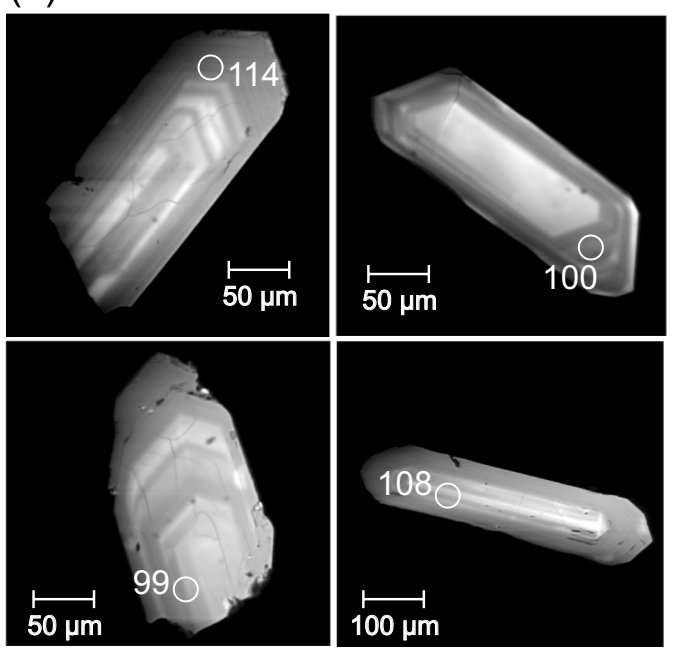

Bt-Ms monzogranite (IG) (c)

data - point error ellipses are $2 \sigma$

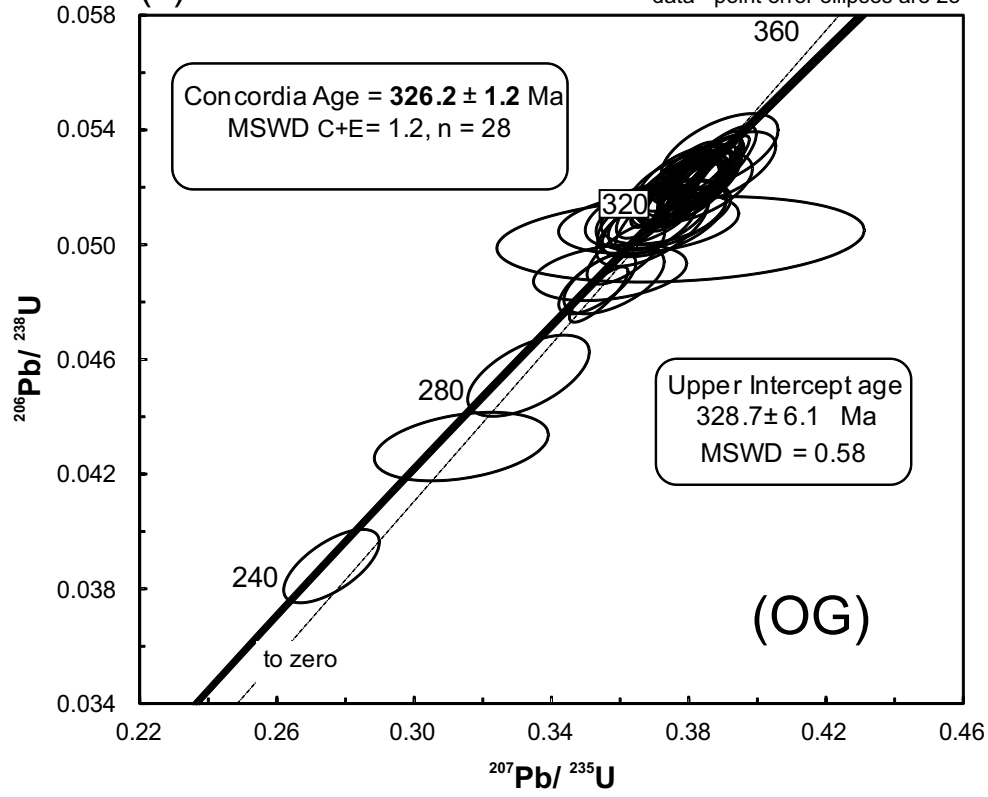

(d)

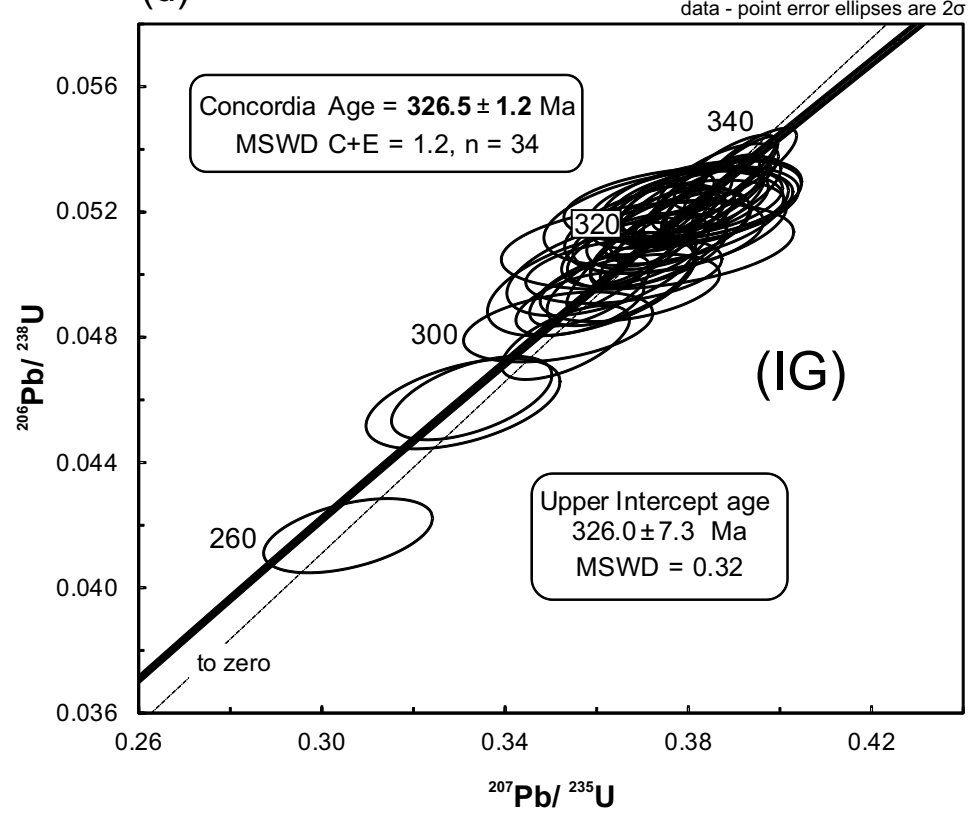

Fig. 3 Representative CL images (a-b) and zircon U-Pb concordia plots (c-d) for the LA ICP-MS data from the OG and IG pulses. All the underlying isotope data including the inherited ages are listed in Supplementary material 2.

The REE contents in the SCS granites drop dramatically inwards $(\Sigma \mathrm{REE}=328-428 \mathrm{ppm}$ for $\mathrm{OG}, 46-66$ ppm IG and 26-28 ppm for LG; Tab. 3). The chondritenormalized patterns (Boynton 1984; Fig. 6b) become less steep from $\mathrm{OG}$ to $\mathrm{IG}+\mathrm{LG}\left(\mathrm{La}_{\mathrm{N}} / \mathrm{Yb}_{\mathrm{N}}=15.7-16.8 \mathrm{OG}\right.$; 6.6-7.5 IG and 5.0-7.1 LG). Typical is the presence of negative $\mathrm{Eu}$ anomalies, the magnitude of which decreases from the pluton's margin $\left(\mathrm{OG} ; \mathrm{Eu} / \mathrm{Eu}^{*}=0.2\right)$ inwards $(\mathrm{IG}$ $\left.+\mathrm{LG} ; \mathrm{Eu} / \mathrm{Eu}^{*}=0.4-0.2\right)$. The IG and LG units show the lanthanide tetrad effect (Masuda et al. 1987) of the third (Gd-Ho) and fourth (Er-Lu) groups of REE (Tab. 3).

\subsubsection{Zircon, monazite and rutile saturation temperatures}

The decrease in $\mathrm{Zr}$ contents with increasing silica indicates that the magma was saturated in zircon during the whole history and that the zircon thermometry (Watson and Harrison 1983) can be applied (Hoskin et al. 2000; Miller et al. 2003; Janoušek 2006). The average zircon saturation temperatures (Fig. 7a) are $833 \pm 6^{\circ} \mathrm{C}$ for OG; $698 \pm 9^{\circ} \mathrm{C}$ for IG and $663 \pm 5^{\circ} \mathrm{C}$ for LG $(2 \sigma$, excluding the calibration and analytical errors). Even though 
Tab. 1 Major-element whole-rock geochemical analyses from the Sedmihoří Composite Stock (in wt. \%)

\begin{tabular}{|c|c|c|c|c|c|c|c|}
\hline Sample & SH13 & SH8 & $\mathrm{SH} 7$ & SH5 & $\mathrm{SH} 3$ & SH6 & SH1 \\
\hline Petrology & Bt monzogranite & Bt monzogranite & Bt monzogranite & Bt monzogranite & Bt monzogranite & Bt monzogranite & Bt monzogranite \\
\hline Intrusion & $\mathrm{OG}$ & OG & $\mathrm{OG}$ & OG & OG & $\mathrm{OG}$ & OG \\
\hline Localization & N 49.629687 & N 49.606741 & N 49.605468 & N 49.620807 & N 49.629080 & N 49.606637 & N 49.634056 \\
\hline (WGS 84) & E 12.869799 & E 12.896648 & E 12.887318 & E 12.857951 & E 12.868891 & E 12.869296 & E 12.885528 \\
\hline $\mathrm{SiO}_{2}$ & 71.63 & 71.69 & 71.76 & 71.76 & 71.91 & 72.08 & 72.30 \\
\hline $\mathrm{TiO}_{2}$ & 0.24 & 0.23 & 0.23 & 0.24 & 0.23 & 0.22 & 0.22 \\
\hline $\mathrm{Al}_{2} \mathrm{O}_{3}$ & 14.27 & 14.31 & 14.05 & 14.38 & 13.90 & 13.93 & 13.98 \\
\hline $\mathrm{Fe}_{2} \mathrm{O}_{3}$ & 1.17 & 0.98 & 0.80 & 0.74 & 0.75 & 0.84 & 0.79 \\
\hline $\mathrm{FeO}$ & 1.21 & 1.18 & 1.42 & 1.54 & 1.49 & 1.43 & 1.38 \\
\hline $\mathrm{MgO}$ & 0.31 & 0.28 & 0.29 & 0.30 & 0.30 & 0.30 & 0.31 \\
\hline $\mathrm{MnO}$ & 0.053 & 0.044 & 0.049 & 0.051 & 0.048 & 0.053 & 0.050 \\
\hline $\mathrm{CaO}$ & 1.14 & 1.06 & 1.17 & 1.20 & 1.20 & 1.24 & 1.23 \\
\hline $\mathrm{Li}_{2} \mathrm{O}$ & 0.016 & 0.008 & 0.018 & 0.019 & 0.017 & 0.015 & 0.017 \\
\hline $\mathrm{Na}_{2} \mathrm{O}$ & 3.81 & 3.68 & 3.68 & 3.72 & 3.67 & 3.73 & 3.69 \\
\hline $\mathrm{K}_{2} \mathrm{O}$ & 5.08 & 5.22 & 5.19 & 4.97 & 5.06 & 4.88 & 5.07 \\
\hline $\mathrm{P}_{2} \mathrm{O}_{5}$ & 0.067 & 0.063 & 0.059 & 0.073 & 0.065 & 0.075 & 0.075 \\
\hline $\mathrm{F}$ & 0.16 & 0.11 & 0.17 & 0.19 & 0.12 & 0.15 & 0.15 \\
\hline $\mathrm{H}_{2} \mathrm{O}^{+}$ & 0.62 & 0.60 & 0.54 & 0.62 & 0.57 & 0.54 & 0.58 \\
\hline $\mathrm{H}_{2} \mathrm{O}^{-}$ & 0.12 & 0.11 & 0.10 & 0.09 & 0.09 & 0.09 & 0.08 \\
\hline $\mathrm{B}_{2} \mathrm{O}_{3}$ & - & - & - & - & - & - & - \\
\hline Total & 99.97 & 99.64 & 99.62 & 99.99 & 99.53 & 99.68 & 99.98 \\
\hline$\overline{\mathrm{A} / \mathrm{CNK}}$ & 1.03 & 1.05 & 1.02 & 1.05 & 1.01 & 1.02 & 1.01 \\
\hline
\end{tabular}

Tab. 1 Continued

\begin{tabular}{|c|c|c|c|c|c|c|c|}
\hline Sample & SH9 & SH4 & $\mathrm{SH} 2$ & SH12 & SH14 & SH11 & SH10 \\
\hline Petrology & Bt monzogranite & Bt monzogranite & $\begin{array}{c}\text { Ms-Bt } \\
\text { monzogranite }\end{array}$ & $\begin{array}{c}\text { Ms-Bt } \\
\text { monzogranite }\end{array}$ & $\begin{array}{c}\text { Ms-Bt } \\
\text { monzogranite }\end{array}$ & $\begin{array}{c}\text { Tur-Ms } \\
\text { monzogranite }\end{array}$ & $\begin{array}{c}\text { Tur-Ms } \\
\text { monzogranite }\end{array}$ \\
\hline Intrusion & OG & OG & IG & $\mathrm{IG}$ & IG & LG & LG \\
\hline Localization & N 49.612407 & N 49.62354 & N 49.626809 & N 49.621257 & N 49.611689 & N 49.615011 & N 49.615176 \\
\hline (WGS 84) & E 12.905463 & E 12.85794 & E 12.875238 & E 12.872292 & E 12.868911 & E 12.878815 & E 12.878999 \\
\hline $\mathrm{SiO}_{2}$ & 72.39 & 72.48 & 73.75 & 73.92 & 74.21 & 73.64 & 74.11 \\
\hline $\mathrm{TiO}_{2}$ & 0.24 & 0.21 & 0.10 & 0.11 & 0.11 & 0.05 & 0.06 \\
\hline $\mathrm{Al}_{2} \mathrm{O}_{3}$ & 13.69 & 13.89 & 14.39 & 14.28 & 14.15 & 14.57 & 14.44 \\
\hline $\mathrm{Fe}_{2} \mathrm{O}_{3}$ & 0.95 & 0.75 & 0.31 & 0.34 & 0.21 & 0.18 & 0.26 \\
\hline $\mathrm{FeO}$ & 1.31 & 1.44 & 0.72 & 0.74 & 0.78 & 0.54 & 0.49 \\
\hline $\mathrm{MgO}$ & 0.33 & 0.27 & 0.22 & 0.27 & 0.22 & 0.15 & 0.15 \\
\hline $\mathrm{MnO}$ & 0.045 & 0.044 & 0.057 & 0.047 & 0.057 & 0.056 & 0.056 \\
\hline $\mathrm{CaO}$ & 1.16 & 1.10 & 0.39 & 0.67 & 0.51 & 0.50 & 0.44 \\
\hline $\mathrm{Li}_{2} \mathrm{O}$ & 0.016 & 0.018 & 0.048 & 0.044 & 0.046 & 0.092 & 0.086 \\
\hline $\mathrm{Na}_{2} \mathrm{O}$ & 3.64 & 3.65 & 3.68 & 3.77 & 3.87 & 4.03 & 3.99 \\
\hline $\mathrm{K}_{2} \mathrm{O}$ & 4.90 & 5.19 & 4.48 & 4.51 & 4.30 & 4.07 & 3.90 \\
\hline $\mathrm{P}_{2} \mathrm{O}_{5}$ & 0.071 & 0.051 & 0.199 & 0.212 & 0.205 & 0.355 & 0.315 \\
\hline $\mathrm{F}$ & 0.17 & 0.14 & 0.15 & 0.16 & 0.13 & 0.28 & 0.27 \\
\hline $\mathrm{H}_{2} \mathrm{O}^{+}$ & 0.56 & 0.55 & 0.94 & 0.68 & 0.81 & 0.89 & 0.86 \\
\hline $\mathrm{H}_{2} \mathrm{O}^{-}$ & 0.10 & 0.11 & 0.17 & 0.13 & 0.10 & 0.09 & 0.09 \\
\hline $\mathrm{B}_{2} \mathrm{O}_{3}$ & - & - & - & - & - & 0.060 & 0.145 \\
\hline Total & 99.67 & 100.00 & 99.68 & 99.96 & 99.78 & 99.55 & 99.60 \\
\hline $\mathrm{A} / \mathrm{CNK}$ & 1.02 & 1.02 & 1.24 & 1.16 & 1.18 & 1.22 & 1.25 \\
\hline
\end{tabular}

"-" not analysed

likely somewhat overestimated due to the presence of inheritance, they seem to indicate a rather high liquidus temperature of the magma parental to the OG. Also, the average monazite saturation temperatures (Montel 1993) are generally comparable with the zircon saturation temperatures (Fig. $7 \mathrm{~b}$ ): $864 \pm 10^{\circ} \mathrm{C}(\mathrm{OG}), 726 \pm 9^{\circ} \mathrm{C}$
(IG) and $681 \pm 6^{\circ} \mathrm{C}$ (LG). Lastly, the magma temperature was estimated using the rutile saturation temperatures (Fig. 7c). The recent model of Kularatne and Audétat (2014), calibrated at a relevant pressure of $2 \mathrm{kbar}$, yields saturation temperatures of $800 \pm 4{ }^{\circ} \mathrm{C}(\mathrm{OG}), 732 \pm 4{ }^{\circ} \mathrm{C}$ (IG) and $680 \pm 7^{\circ} \mathrm{C},(\mathrm{LG})$, respectively. 
Tab. 2 Trace-element (except REE) whole-rock geochemical analyses from the Sedmihoří Composite Stock (in ppm)

\begin{tabular}{|c|c|c|c|c|c|c|c|}
\hline Sample & SH13 & SH8 & SH7 & SH5 & SH3 & SH6 & SH1 \\
\hline Petrology & Bt monzogranite & Bt monzogranite & Bt monzogranite & Bt monzogranite & Bt monzogranite & Bt monzogranite & Bt monzogranite \\
\hline Intrusion & OG & OG & OG & OG & OG & OG & OG \\
\hline $\mathrm{Ba}$ & 258 & 294 & 271 & 273 & 269 & 260 & 293 \\
\hline $\mathrm{Rb}$ & 244 & 241 & 254 & 266 & 239 & 246 & 247 \\
\hline $\mathrm{Sr}$ & 55 & 58 & 54 & 54 & 57 & 56 & 60 \\
\hline Cs & 13.0 & 10.4 & 15.5 & 17.9 & 12.2 & 10.4 & 15.3 \\
\hline $\mathrm{Ga}$ & 22 & 22 & 22 & 22 & 22 & 22 & 21 \\
\hline $\mathrm{Ge}$ & 2.1 & 2.0 & 2.1 & 2.3 & 2.1 & 2.4 & 2.1 \\
\hline $\mathrm{Nb}$ & 14.9 & 14.4 & 14.6 & 15.8 & 14.9 & 15.8 & 14.0 \\
\hline $\mathrm{Ta}$ & 1.3 & 1.2 & 1.6 & 1.9 & 1.2 & 1.3 & 1.4 \\
\hline $\mathrm{Th}$ & 52.5 & 52.1 & 47.5 & 50.9 & 50.3 & 51.9 & 43.0 \\
\hline $\mathrm{U}$ & 10.7 & 7.8 & 8.4 & 8.8 & 8.8 & 12.2 & 7.2 \\
\hline $\mathrm{Zr}$ & 289 & 289 & 266 & 274 & 276 & 296 & 254 \\
\hline $\mathrm{Hf}$ & 8.6 & 8.3 & 8.1 & 8.3 & 8.2 & 8.9 & 7.6 \\
\hline $\mathrm{Cu}$ & $<10$ & $<10$ & $<10$ & 20 & $<10$ & $<10$ & $<10$ \\
\hline $\mathrm{Pb}$ & 59 & 51 & 50 & 55 & 52 & 54 & 57 \\
\hline $\mathrm{Zn}$ & 70 & 60 & 60 & 70 & 70 & 70 & 60 \\
\hline Co & 1 & 1 & 1 & 1 & 1 & 1 & 1 \\
\hline As & 7 & $<5$ & 14 & $<5$ & $<5$ & $<5$ & 14 \\
\hline $\mathrm{Ag}$ & 1.5 & 1.7 & 1.5 & 1.5 & 1.5 & 1.7 & 1.6 \\
\hline $\mathrm{Sb}$ & 0.3 & $<0.2$ & 0.2 & 0.3 & $<0.2$ & $<0.2$ & 0.3 \\
\hline $\mathrm{Bi}$ & 1.4 & 1.1 & 0.8 & 1.4 & 1.3 & 0.3 & 1.6 \\
\hline V & $<5$ & 5 & 5 & 6 & 5 & 5 & 6 \\
\hline $\mathrm{Cr}$ & $<20$ & $<20$ & $<20$ & $<20$ & $<20$ & $<20$ & $<20$ \\
\hline $\mathrm{Sn}$ & 12 & 11 & 11 & 15 & 10 & 11 & 12 \\
\hline W & 1.9 & 1.7 & 3.5 & 3.2 & 1.4 & 2.5 & 2.5 \\
\hline $\mathrm{Tl}$ & 1.9 & 1.6 & 1.7 & 1.7 & 1.7 & 1.7 & 1.7 \\
\hline $\mathrm{Rb} / \mathrm{Sr}$ & 4.44 & 4.16 & 4.70 & 4.93 & 4.19 & 4.39 & 4.12 \\
\hline
\end{tabular}

Tab. 2. Continued

\begin{tabular}{|c|c|c|c|c|c|c|c|}
\hline $\begin{array}{l}\text { Sample } \\
\text { Petrology } \\
\text { Intrusion }\end{array}$ & $\begin{array}{c}\text { SH9 } \\
\text { Bt monzogranite } \\
\text { OG }\end{array}$ & $\begin{array}{c}\text { SH4 } \\
\text { Bt monzogranite } \\
\text { OG }\end{array}$ & $\begin{array}{c}\mathrm{SH} 2 \\
\mathrm{Ms}-\mathrm{Bt} \\
\text { monzogranite } \\
\text { IG }\end{array}$ & $\begin{array}{c}\text { SH12 } \\
\text { Ms-Bt } \\
\text { monzogranite } \\
\text { IG }\end{array}$ & $\begin{array}{c}\text { SH14 } \\
\text { Ms-Bt } \\
\text { monzogranite } \\
\text { IG }\end{array}$ & $\begin{array}{c}\text { SH11 } \\
\text { Tur-Ms } \\
\text { monzogranite } \\
\text { LG }\end{array}$ & $\begin{array}{c}\text { SH10 } \\
\text { Tur-Ms } \\
\text { monzogranite } \\
\text { LG }\end{array}$ \\
\hline $\mathrm{Ba}$ & 269 & 259 & 94 & 186 & 92 & 49 & 46 \\
\hline $\mathrm{Rb}$ & 236 & 247 & 401 & 374 & 373 & 568 & 547 \\
\hline $\mathrm{Sr}$ & 56 & 51 & 26 & 44 & 24 & 15 & 16 \\
\hline Cs & 11.5 & 9.4 & 32.0 & 27.0 & 38.9 & 86.8 & 90.8 \\
\hline $\mathrm{Ga}$ & 21 & 22 & 22 & 21 & 22 & 26 & 25 \\
\hline $\mathrm{Ge}$ & 2.1 & 2.2 & 2.9 & 3.1 & 3.0 & 4.1 & 3.8 \\
\hline $\mathrm{Nb}$ & 14.4 & 15.0 & 11.9 & 11.1 & 11.1 & 17.3 & 16.6 \\
\hline $\mathrm{Ta}$ & 1.2 & 1.2 & 2.9 & 2.9 & 2.2 & 6.1 & 5.0 \\
\hline Th & 46.8 & 50.3 & 7.1 & 9.4 & 7.0 & 3.7 & 3.7 \\
\hline $\mathrm{U}$ & 8.4 & 11.7 & 4.9 & 3.6 & 3.7 & 3.0 & 3.0 \\
\hline $\mathrm{Zr}$ & 252 & 287 & 41 & 54 & 40 & 25 & 28 \\
\hline $\mathrm{Hf}$ & 7.5 & 8.4 & 1.6 & 1.9 & 1.5 & 1.3 & 1.3 \\
\hline $\mathrm{Cu}$ & $<10$ & 10 & $<10$ & $<10$ & $<10$ & $<10$ & $<10$ \\
\hline $\mathrm{Pb}$ & 58 & 54 & 26 & 32 & 29 & 16 & 16 \\
\hline $\mathrm{Zn}$ & 60 & 70 & 40 & 50 & 40 & 40 & 50 \\
\hline Co & 2 & 1 & $<1$ & $<1$ & $<1$ & $<1$ & $<1$ \\
\hline As & $<5$ & $<5$ & $<5$ & $<5$ & 11 & $<5$ & $<5$ \\
\hline $\mathrm{Ag}$ & 1.5 & 1.6 & $<0.5$ & $<0.5$ & $<0.5$ & $<0.5$ & $<0.5$ \\
\hline $\mathrm{Sb}$ & 0.2 & 0.3 & $<0.2$ & $<0.2$ & 0.2 & $<0.2$ & $<0.2$ \\
\hline $\mathrm{Bi}$ & 1.1 & 0.4 & 5.2 & 3.8 & 3.7 & 6.4 & 4.7 \\
\hline V & 6 & 6 & $<5$ & $<5$ & $<5$ & $<5$ & $<5$ \\
\hline $\mathrm{Cr}$ & 20 & $<20$ & $<20$ & $<20$ & $<20$ & $<20$ & $<20$ \\
\hline Sn & 10 & 11 & 40 & 35 & 33 & 80 & 71 \\
\hline W & 0.8 & 0.8 & 4.8 & 4.2 & 5.2 & 8.9 & 20.2 \\
\hline $\mathrm{Tl}$ & 1.7 & 1.8 & 2.7 & 2.7 & 2.7 & 3.8 & 3.7 \\
\hline $\mathrm{Rb} / \mathrm{Sr}$ & 4.21 & 4.84 & 15.42 & 8.50 & 15.54 & 37.87 & 34.19 \\
\hline
\end{tabular}

Numbers following the "lower than" sign indicate determinations that were below detection limit 

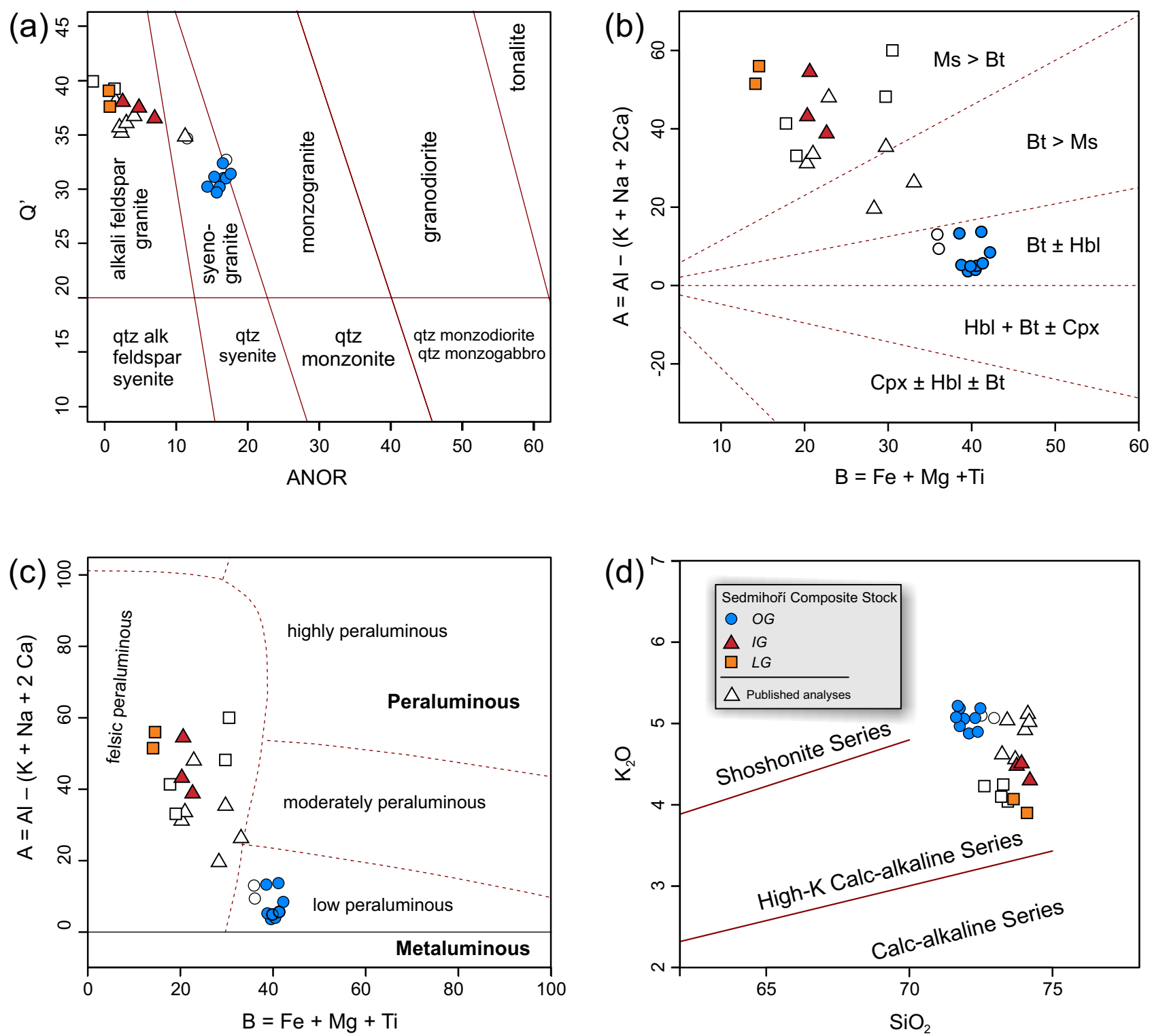

Fig. 4 Major-element based classifications. a - Diagram of the normative compositions Q'-ANOR (Streckeisen and Le Maitre 1979) calculated using Improved Granite Mesonorm (Mielke and Winkler 1979). b - B-A multicationic plot after Debon and Le Fort (1983). c - The same plot modified by Villaseca et al. (1998). d $-\mathrm{SiO}_{2}-\mathrm{K}_{2} \mathrm{O}$ (wt. \%) diagram of Peccerillo and Taylor (1976). Published analyses (empty symbols) are from Ali-Bik (1996) and Voves et al. (1997).

\subsection{Radiogenic isotopes}

In order to further constrain geochemical variations in the pluton, six new samples were analyzed for their $\mathrm{Sr}-\mathrm{Nd}$ isotopic composition (Tab. 4; Fig. 8). Three additional $\mathrm{Sr}$ isotopic analyses were taken from Voves et al. (1997).

All the two main units of the SCS are characterized by crust-like $\mathrm{Sr}-\mathrm{Nd}$ isotopic signatures (OG: ${ }^{87} \mathrm{Sr} /{ }^{86} \mathrm{Sr}_{326}$ $=0.7067$ and 0.7076 and $\varepsilon \mathrm{Nd}_{326}=-2.5$ and -2.7 ; IG: ${ }^{87} \mathrm{Sr} /{ }^{86} \mathrm{Sr}_{326}=0.7098-0.7154 ; \varepsilon^{26 \mathrm{Nd}_{326}}=-3.7$ and -4.6 ). The innermost LG has very high $\mathrm{Rb} / \mathrm{Sr}$ ratios, resulting in unrealistically low initial $\mathrm{Sr}$ ratios $\left({ }^{87} \mathrm{Sr}^{186} \mathrm{Sr}_{326}=0.6775\right.$ and 0.7036$)$. The $\mathrm{Nd}$ isotopic signature resembles the $\mathrm{IG}$ $\left(\varepsilon \mathrm{Nd}_{326}=-3.6\right.$ and -4.2$)$. The depleted-mantle Nd model ages (calculated using the two-stage model of Liew and Hofmann 1988) differ slightly between OG (1.25 Ga) and IG with LG (1.33-1.40 Ga).

\section{Discussion}

The presented data from the SCS rule out a shallowlevel fractionation or contamination by the countryrock metasediments, and point to processes deeper in the crust and/or significant differences in source 

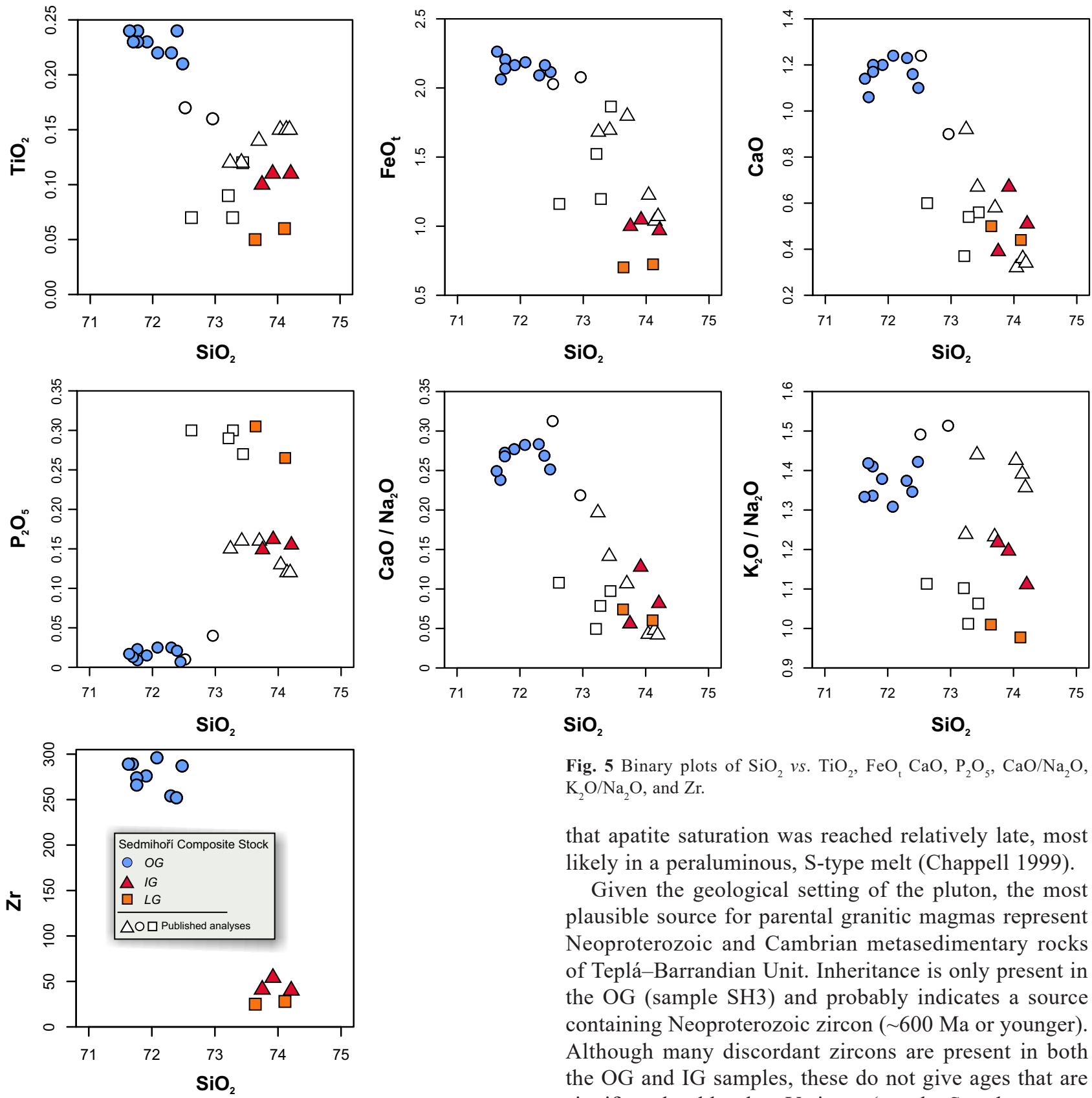

Fig. 5 Binary plots of $\mathrm{SiO}_{2}$ vs. $\mathrm{TiO}_{2}, \mathrm{FeO}_{\mathrm{t}} \mathrm{CaO}, \mathrm{P}_{2} \mathrm{O}_{5}, \mathrm{CaO} / \mathrm{Na}_{2} \mathrm{O}$, $\mathrm{K}_{2} \mathrm{O} / \mathrm{Na}_{2} \mathrm{O}$, and $\mathrm{Zr}$.

that apatite saturation was reached relatively late, most likely in a peraluminous, S-type melt (Chappell 1999).

Given the geological setting of the pluton, the most plausible source for parental granitic magmas represent Neoproterozoic and Cambrian metasedimentary rocks of Teplá-Barrandian Unit. Inheritance is only present in the OG (sample SH3) and probably indicates a source containing Neoproterozoic zircon ( $600 \mathrm{Ma}$ or younger). Although many discordant zircons are present in both the OG and IG samples, these do not give ages that are significantly older than Variscan (see the Supplementary

materials. These processes and differences are discussed below.

\subsection{Magma source}

\subsubsection{Major- and trace-element constraints}

The ratio $\mathrm{CaO} / \mathrm{Na}_{2} \mathrm{O}(<0.3)$ as well as the $\mathrm{Rb} / \mathrm{Sr}(\mathrm{OG}$ : 4.1-4.9; LG + IG: 8.5-37.9) and Rb/Ba (OG: 0.8-1; IG + LG: 2.0-11.9) indicate a metapsammitic parentage (Sylvester 1998). Also, the high content of phosphorus in all units of the SCS $\left(0.05-0.35\right.$ wt. $\left.\% \mathrm{P}_{2} \mathrm{O}_{5}\right)$ indicates

\subsection{2. $\mathrm{Sr}-\mathrm{Nd}$ isotopic evidence for open-system behaviour}

All the three main units of the SCS are characterized by crust-like $\mathrm{Sr}-\mathrm{Nd}$ isotopic signatures $\left({ }^{87} \mathrm{Sr} /{ }^{86} \mathrm{Sr}_{326}=\right.$ $0.7067-0.7154 ; \varepsilon \mathrm{Nd}_{326}=-2.5$ to -4.6 ).

The $\mathrm{Sr}-\mathrm{Nd}$ isotopic compositions for the Neoproterozoic or Cambrian material from the Teplá-Barrandian Unit are highly variable $\left({ }^{87} \mathrm{Sr}{ }^{86} \mathrm{Sr}_{326}=0.7070-0.7262\right.$; $\varepsilon \mathrm{Nd}_{326}-14.3$ to -0.3 : Janoušek et al. 1995; Drost et 


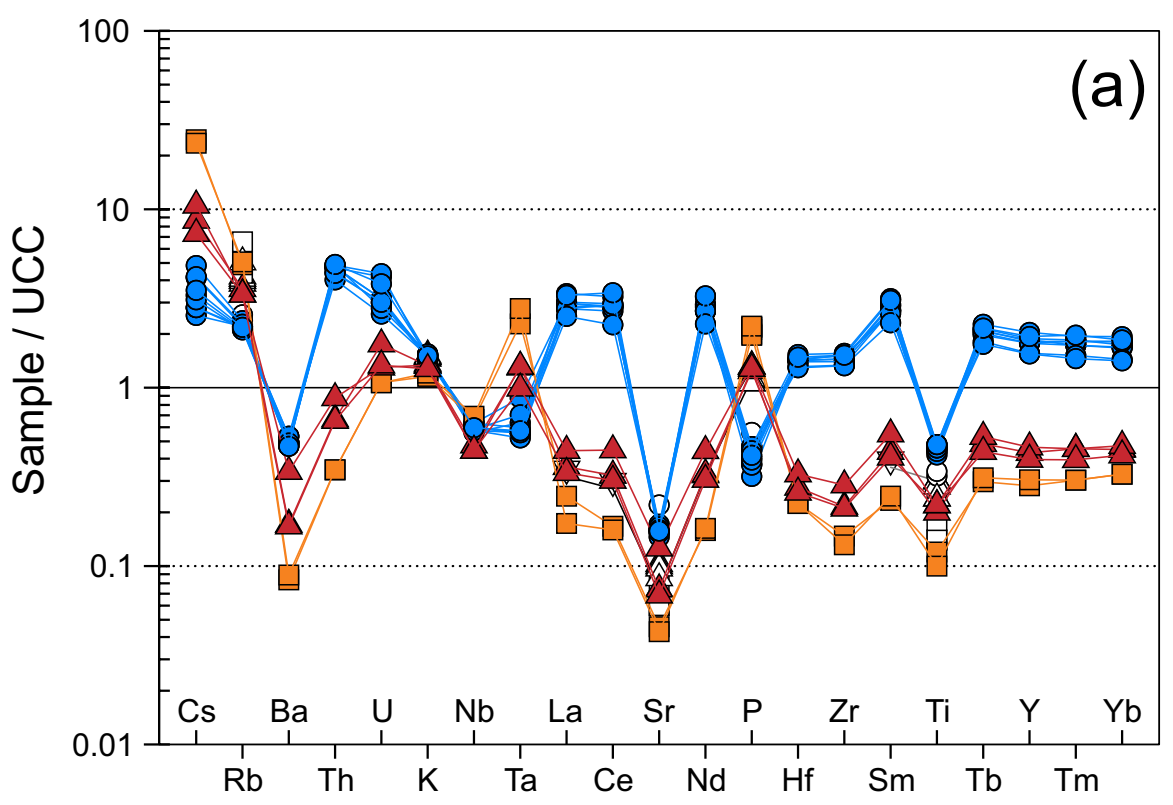

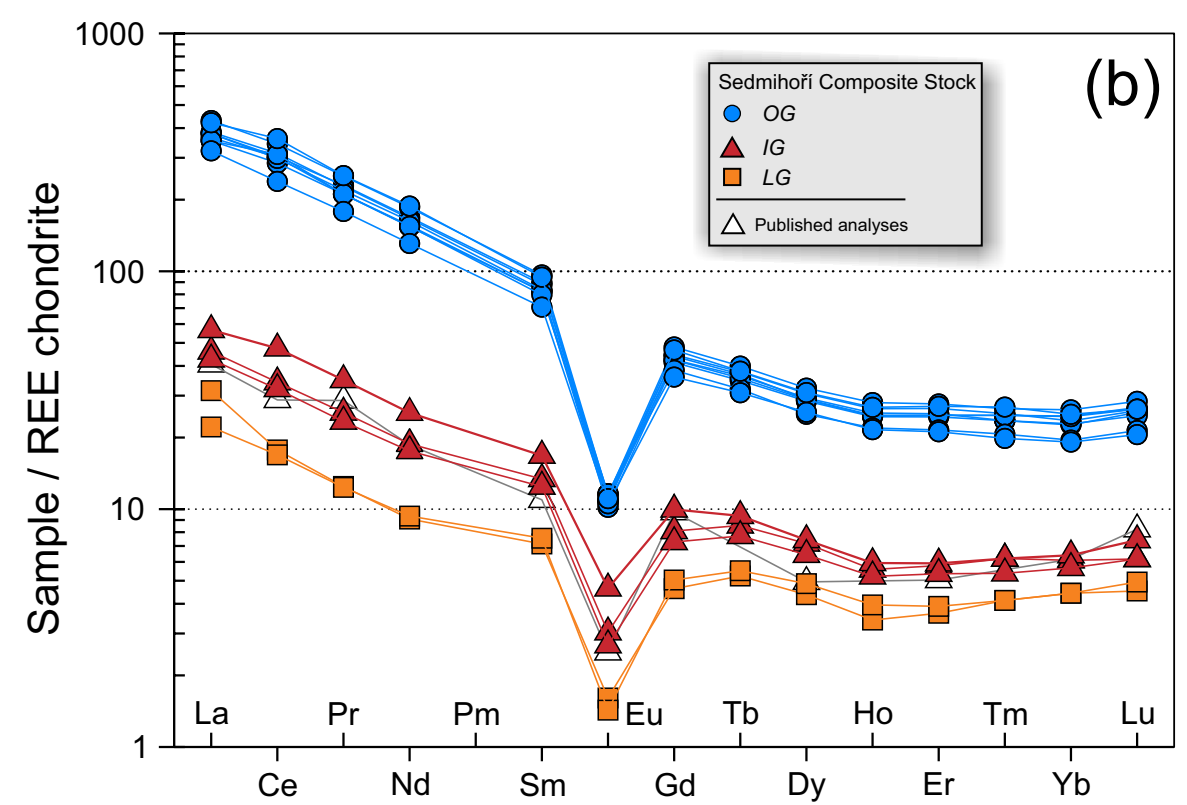

Fig. 6 Spider plots of (a) trace-element contents normalized to the average composition of the Upper Continental Crust (Taylor and McLennan 1995) and (b) REE abundances normalized to chondrite (Boynton 1984). al. 2007; Pin and Waldhausrová 2007; Drost 2008 and unpublished data of the authors; Fig. 8a). They indeed almost overlap with the compositions of the SCS granitoids.

For late Variscan magmatic rocks from SW Bohemia, Fig. 8a-b shows a rather broad isotopic variation compatible with an open-system evolution. The hyperbolic trends were most likely caused by binary mixing between felsic and basic end-members. In the SCS, the basic input was particularly important in the OG unit where it is recorded as abundant MME. However, it was also significant in the nearby Bor Pluton, the more distant Loket Pluton as well as the redwitzite bodies (Siebel 1993; Siebel et al. 2003; Ackerman et al. 2010; Kováŕíková et al. 2007, 2010).
These potassic, Kfs-poor Amp-Bt dioritoids-gabbroids, originally named by Willmann (1919) after Marktredwitz in Bavaria, form a conspicuous $\sim 323$ Ma suite in Fichtelgebirge and W Erzgebirge/Slavkovský les.

The $\mathrm{Sr}-\mathrm{Nd}$ isotopic compositions of redwitzites $\left({ }^{87} \mathrm{Sr} /{ }^{86} \mathrm{Sr}_{326}=0.7057-0.7115 ; \varepsilon \mathrm{Nd}_{326}-4.9\right.$ to -0.7 ; Holl et al. 1989; Taubald 2000), granodiorites of Bor Pluton $\left({ }^{87} \mathrm{Sr} /{ }^{86} \mathrm{Sr}_{326}=0.7064-0.7085 ; \varepsilon \mathrm{Nd}_{326}-5.0\right.$ to -2.8 ; Siebel et al. 1999), diorites of Drahotín Pluton $\left({ }^{87} \mathrm{Sr} /{ }^{86} \mathrm{Sr}_{326}\right.$ $=0.7073-0.7093 ; \varepsilon \mathrm{Nd}_{326}-5.9$ to -3.4 ; Ackerman et al. 2010) support the idea about mafic magma input because they mostly resemble, or are somewhat more primitive than, the compositions of the OG samples (Fig. 8a). 
Tab. 3 Rare-earth element and yttrium whole-rock geochemical analyses from the Sedmihoří Composite Stock (in ppm)

\begin{tabular}{|c|c|c|c|c|c|c|c|}
\hline Sample & SH13 & SH8 & SH7 & SH5 & $\mathrm{SH} 3$ & SH6 & SH1 \\
\hline Petrology & Bt monzogranite & Bt monzogranite & Bt monzogranite & Bt monzogranite & Bt monzogranite & Bt monzogranite & Bt monzogranite \\
\hline Intrusion & $\mathrm{OG}$ & $\mathrm{OG}$ & $\mathrm{OG}$ & OG & $\mathrm{OG}$ & $\mathrm{OG}$ & $\mathrm{OG}$ \\
\hline $\mathrm{Y}$ & 42.6 & 34.3 & 39.1 & 39.9 & 41.4 & 44.9 & 40.8 \\
\hline $\mathrm{La}$ & 98.9 & 83.0 & 89.0 & 90.4 & 89.0 & 101.0 & 83.1 \\
\hline $\mathrm{Ce}$ & 218 & 187 & 180 & 189 & 183 & 207 & 172 \\
\hline $\operatorname{Pr}$ & 22.5 & 18.8 & 19.5 & 20.3 & 20.5 & 22.4 & 18.8 \\
\hline $\mathrm{Nd}$ & 85.1 & 69.9 & 73.5 & 75.3 & 76.4 & 83.9 & 70.5 \\
\hline $\mathrm{Sm}$ & 13.9 & 11.7 & 12.3 & 12.9 & 13.2 & 14.2 & 12.1 \\
\hline $\mathrm{Eu}$ & 0.62 & 0.65 & 0.60 & 0.65 & 0.61 & 0.64 & 0.61 \\
\hline $\mathrm{Gd}$ & 9.18 & 7.54 & 8.32 & 8.64 & 8.77 & 9.45 & 8.35 \\
\hline $\mathrm{Tb}$ & 1.38 & 1.16 & 1.29 & 1.34 & 1.37 & 1.45 & 1.32 \\
\hline Dy & 7.50 & 6.08 & 7.00 & 7.03 & 7.43 & 7.83 & 7.12 \\
\hline Ho & 1.49 & 1.22 & 1.37 & 1.38 & 1.47 & 1.56 & 1.41 \\
\hline $\mathrm{Er}$ & 4.30 & 3.42 & 3.94 & 3.94 & 4.21 & 4.40 & 4.00 \\
\hline $\mathrm{Tm}$ & 0.65 & 0.50 & 0.60 & 0.60 & 0.61 & 0.64 & 0.57 \\
\hline $\mathrm{Yb}$ & 4.07 & 3.17 & 3.98 & 4.00 & 3.82 & 4.25 & 3.67 \\
\hline $\mathrm{Lu}$ & 0.64 & 0.52 & 0.64 & 0.65 & 0.63 & 0.69 & 0.62 \\
\hline$\Sigma$ REE & 468.2 & 394.7 & 402.0 & 416.1 & 411.0 & 459.4 & 384.2 \\
\hline $\mathrm{La}_{\mathrm{N}} / \mathrm{Yb}_{\mathrm{N}}$ & 16.38 & 17.65 & 15.08 & 15.24 & 15.71 & 16.02 & 15.27 \\
\hline $\mathrm{Eu} / \mathrm{Eu}^{*}$ & 0.17 & 0.21 & 0.18 & 0.19 & 0.17 & 0.17 & 0.19 \\
\hline $\mathrm{TE}_{1}$ & 1.118 & 1.140 & 1.073 & 1.100 & 1.088 & 1.084 & 1.088 \\
\hline $\mathrm{TE}_{3}$ & 0.952 & 0.959 & 0.947 & 0.973 & 0.973 & 0.961 & 0.978 \\
\hline
\end{tabular}

Tab. 3 Continued

\begin{tabular}{|c|c|c|c|c|c|c|c|}
\hline Petrology & Bt monzogranite & $\begin{array}{c}\text { SH4 } \\
\text { Bt monzogranite }\end{array}$ & $\begin{array}{c}\mathrm{SH} 2 \\
\mathrm{Ms}-\mathrm{Bt} \\
\text { monzogranite }\end{array}$ & $\begin{array}{c}\text { SH12 } \\
\text { Ms-Bt } \\
\text { monzogranite }\end{array}$ & $\begin{array}{c}\text { SH14 } \\
\text { Ms-Bt } \\
\text { monzogranite }\end{array}$ & $\begin{array}{c}\text { SH11 } \\
\text { Tur-Ms } \\
\text { monzogranite }\end{array}$ & $\begin{array}{c}\text { SH10 } \\
\text { Tur-Ms } \\
\text { monzogranite }\end{array}$ \\
\hline Intrusion & $\mathrm{OG}$ & $\mathrm{OG}$ & IG & IG & IG & LG & LG \\
\hline $\mathrm{Y}$ & 34.0 & 39.0 & 9.5 & 10.2 & 8.7 & 6.7 & 6.2 \\
\hline $\mathrm{La}$ & 75.3 & 85.6 & 10.8 & 13.3 & 10.0 & 5.2 & 7.4 \\
\hline $\mathrm{Ce}$ & 144.0 & 182.0 & 20.6 & 28.6 & 19.3 & 10.2 & 10.7 \\
\hline $\operatorname{Pr}$ & 15.90 & 18.80 & 2.27 & 3.11 & 2.08 & 1.10 & 1.11 \\
\hline $\mathrm{Nd}$ & 59.2 & 69.7 & 8.5 & 11.5 & 7.9 & 4.2 & 4.1 \\
\hline $\mathrm{Sm}$ & 10.40 & 12.10 & 1.97 & 2.47 & 1.83 & 1.11 & 1.05 \\
\hline $\mathrm{Eu}$ & 0.59 & 0.57 & 0.17 & 0.26 & 0.15 & 0.08 & 0.09 \\
\hline $\mathrm{Gd}$ & 7.06 & 8.13 & 1.59 & 1.96 & 1.43 & 0.99 & 0.91 \\
\hline $\mathrm{Tb}$ & 1.12 & 1.26 & 0.31 & 0.34 & 0.28 & 0.20 & 0.19 \\
\hline Dy & 6.20 & 6.91 & 1.74 & 1.80 & 1.56 & 1.18 & 1.06 \\
\hline Ho & 1.20 & 1.36 & 0.31 & 0.33 & 0.29 & 0.22 & 0.19 \\
\hline $\mathrm{Er}$ & 3.36 & 3.88 & 0.92 & 0.94 & 0.85 & 0.62 & 0.58 \\
\hline $\mathrm{Tm}$ & 0.48 & 0.57 & 0.15 & 0.15 & 0.13 & 0.10 & 0.10 \\
\hline $\mathrm{Yb}$ & 3.11 & 3.71 & 0.99 & 1.04 & 0.92 & 0.72 & 0.72 \\
\hline $\mathrm{Lu}$ & 0.50 & 0.60 & 0.15 & 0.18 & 0.15 & 0.12 & 0.11 \\
\hline$\Sigma \mathrm{REE}$ & 328.4 & 395.2 & 50.5 & 66.0 & 46.9 & 26.1 & 28.3 \\
\hline $\mathrm{La}_{\mathrm{N}} / \mathrm{Yb}_{\mathrm{N}}$ & 16.32 & 15.56 & 7.35 & 8.62 & 7.33 & 4.87 & 6.92 \\
\hline $\mathrm{Eu} / \mathrm{Eu}^{*}$ & 0.21 & 0.18 & 0.29 & 0.36 & 0.28 & 0.23 & 0.28 \\
\hline $\mathrm{TE}_{1}$ & 1.050 & 1.109 & 1.045 & 1.117 & 1.042 & 1.046 & 0.916 \\
\hline $\mathrm{TE}_{3}$ & 0.991 & 0.971 & 1.145 & 1.065 & 1.124 & 1.140 & 1.182 \\
\hline
\end{tabular}

Numbers following the "lower than" sign indicate determinations that were below detection limit.

$\mathrm{TE}_{1}=\left(\mathrm{Ce}_{\mathrm{N}} /\left(\mathrm{La}_{\mathrm{N}}^{2 / 3} \times \mathrm{Nd}_{\mathrm{N}}^{1 / 3}\right) \times \operatorname{Pr}_{\mathrm{N}} /\left(\mathrm{La}_{\mathrm{N}}^{1 / 3} \times \mathrm{Nd}_{\mathrm{N}}^{2 / 3}\right)\right)^{1 / 2}, \mathrm{TE}_{3}=\left(\mathrm{Tb}_{\mathrm{N}} /\left(\mathrm{Gd}_{\mathrm{N}}^{2 / 3} \times \mathrm{Ho}_{\mathrm{N}}^{1 / 3}\right) \times \mathrm{Dy}_{\mathrm{N}} /\left(\mathrm{Gd}_{\mathrm{N}}^{1 / 3} \times \mathrm{Ho}_{\mathrm{N}}^{2 / 3}\right)\right)^{1 / 2}$, from $\operatorname{Irber}^{(1999)}$.

The trend in Fig. 8a indicates that the magma parental to the OG magmatic unit could have been created by binary mixing between mature greywacke-derived felsic magma and redwitzitic mafic melt. The source of the SCS probably represented an anatectic zone within chemically heterogeneous Neoproterozoic-Cambrian metasedimentary pile of the Teplá-Barrandian Unit. The higher-level felsic magma chamber was locally affected by hybridiza- 


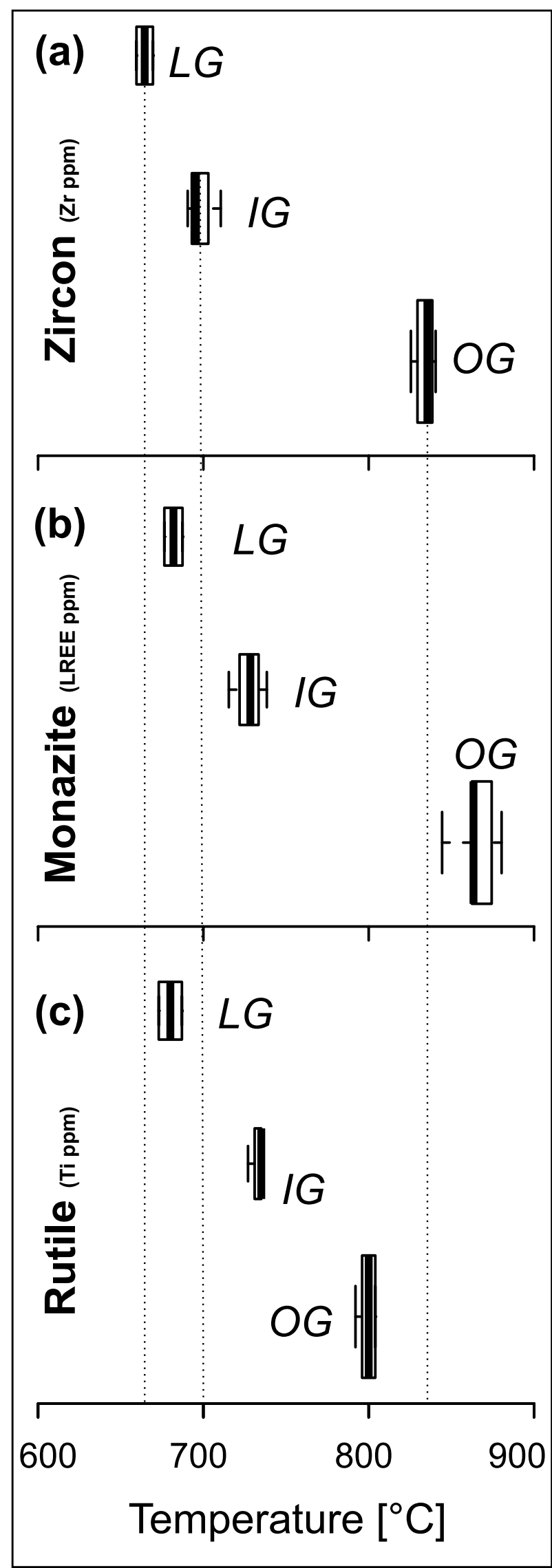

tion/commingling with redwitzitic mafic magma. Figure $8 \mathrm{~b}$ further shows that some late fractional crystallization (FC) affected rocks of the SCS after the mixing event, further lowering the $\mathrm{Sr}$ contents.

\subsection{Magma evolution}

All the petrographic varieties in the SCS are fairly fractionated; in general, the inner pulses, IG and LG, are more evolved than the marginal OG. This is shown, inter alia, by significantly increasing $\mathrm{SiO}_{2}$ contents. Given that the most of fractionation likely took place near or within the granite minimum (see also Bonin et al. in print and references therein), we have opted for $\mathrm{Rb}$ as a fractionation index because of its incompatible behaviour in highly fractionated granitic suites, including ours (Fig. 9).

The change in major- and minor-element oxides is only limited from the pluton margin to the centre. The contents of $\mathrm{SiO}_{2}$ and $\mathrm{P}_{2} \mathrm{O}_{5}$ broadly increase (Fig. 5), while $\mathrm{TiO}_{2}, \mathrm{CaO}$ and $\left(\mathrm{FeO}_{\mathrm{t}}\right)$ show the opposite trend. More significant differences are revealed by trace elements. For the whole pluton, there are inward trends of increase in $\mathrm{Li}$, Cs and $\mathrm{Rb}$ (Fig. 9), and decrease in $\mathrm{Ba}, \mathrm{Sr}, \mathrm{Zr}$, Th, and all segments of the REE patterns. These trends highlight an important role of feldspars-dominated fractionation, accompanied by biotite and some Ti, P, Zr and LREE-rich accessories, such as Rt, Ap, Zrn and Mnz.

The Th contents and U/Th ratios show also marked differences between the $\mathrm{OG}$ and $\mathrm{IG}+\mathrm{LG}$ facies (Figs 6a, 10). The high $\mathrm{Th}$ and $\mathrm{U}$ concentrations need to be hosted by accessory minerals; in the OG by thorite \pm monazite, zircon, in IG + LG units by monazite, zircon \pm xenotime. This difference can be explained by the different magma parental to the OG unit of the SCS, whereby the anatectic magma derived from greywacke sediments interacted with U-Th rich, enriched-mantle derived (redwitzitic) mafic melt. However, the role of monazite accumulation in the genesis of the OG cannot be completely ruled out.

The fractionation in each pulse, respectively in margin and centre of the SCS, is also confirmed by the mineral assemblages that add evidence for the evolution of the magma (Candela 1997). The OG, IG + LG granites contain numerous accessory minerals (see Supplementary material 1; e.g., apatite, zircon, monazite, andalusite, tourmaline, thorite and pseudomorphs after cordierite) which shows different evolution of magma for the OG and the IG + LG units. A high degree of differentiation in the central LG pulse is documented by the occurrence

Fig. 7 Boxplots portraying the statistical distribution of the saturation temperatures for (a) zircon (Watson and Harrison 1983), (b) monazite (Montel 1993), and (c) rutile (Kularatne and Audétat 2014). 

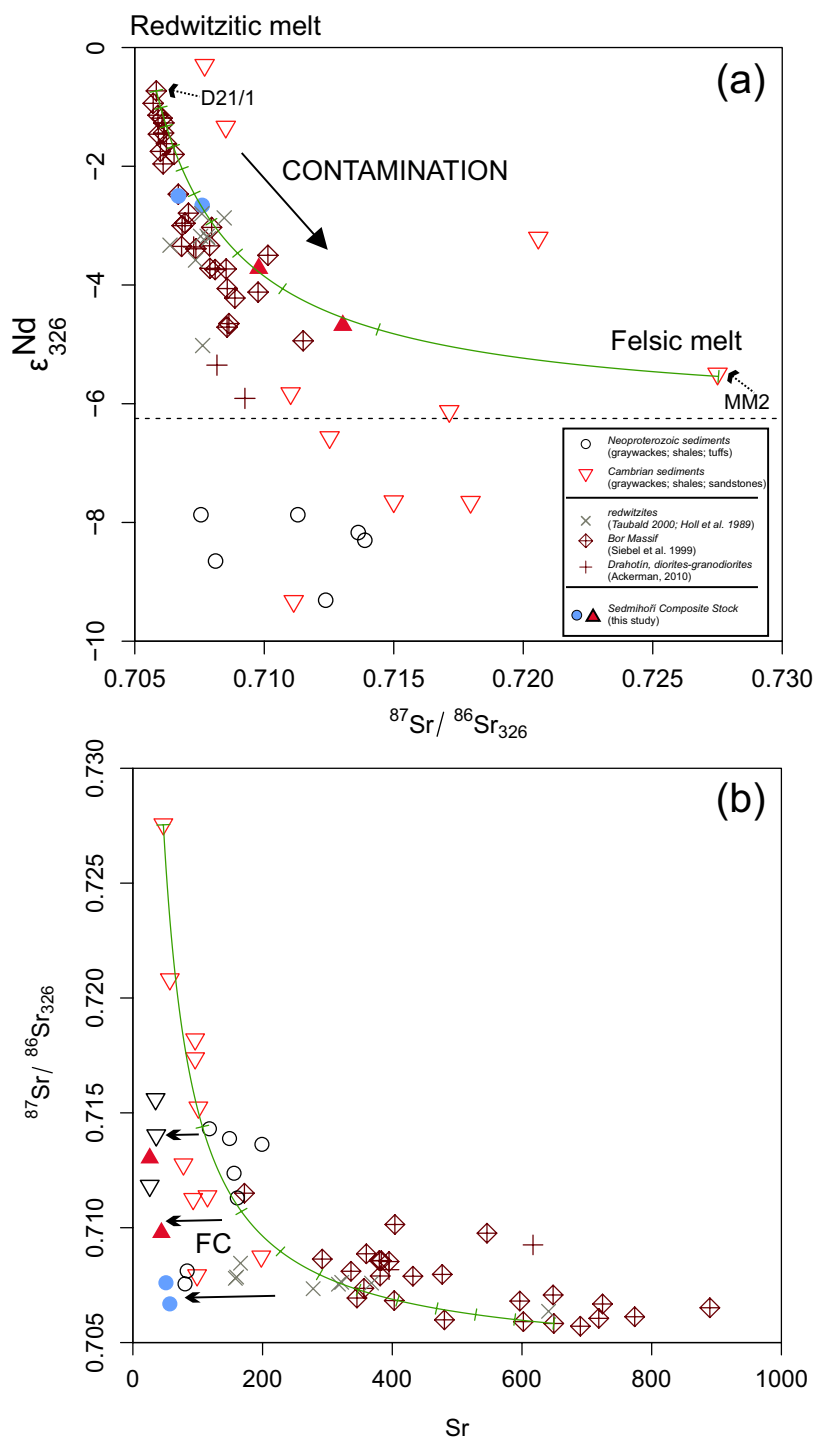

Fig. 8 Binary plots of $\mathrm{Sr}$ and $\mathrm{Nd}$ isotopic compositions from the Sedmihoří Composite Stock recalculated to its radiometric age (326 Ma): $\mathbf{a}-\mathrm{Sr}_{326}$ vs. $\varepsilon \mathrm{Nd}_{326} ; \mathbf{b}-\mathrm{Sr}$ vs. ${ }^{87} \mathrm{Sr} /{ }^{86} \mathrm{Sr}_{326}$ The mixing hyperbolae assuming binary mixing between samples of a redwitzite D21/1 (Holl et al. 1989) and Cambrian shale MM2 (Drost et al. 2007) are also plotted.

of beryl, wolframite or higher levels of lithium, rubidium, fluorine and tin in micas.

Taken together, the degree of fractionation seems to increase from the outer $\mathrm{OG}$ to the inner IG + LG units. This is typically seen in granitic plutons and documents the normal zoning of the SCS. Still, each of the units preserves its remarkable compositional homogeneity and represents a single batch of magma with its own geochemical characteristics and petrogenesis.

\subsection{Timing of intrusion in a regional context}

In the Bohemian Massif, two post-collisional to postorogenic magmatic provinces have been recognized

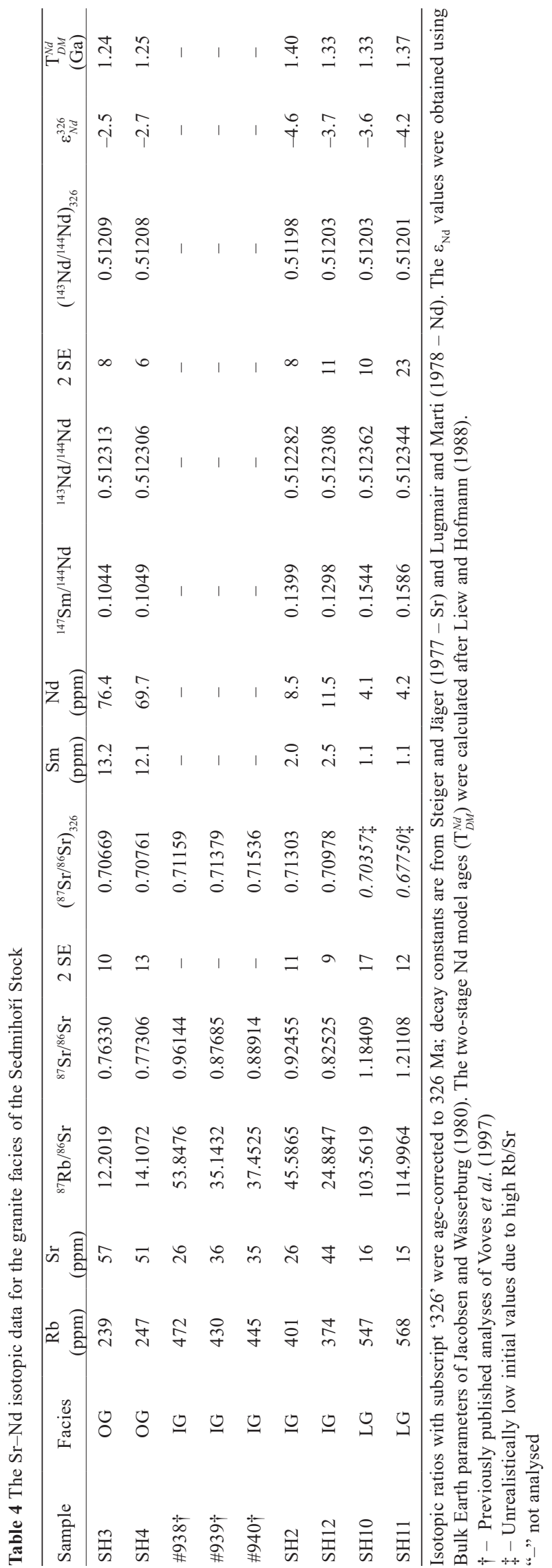



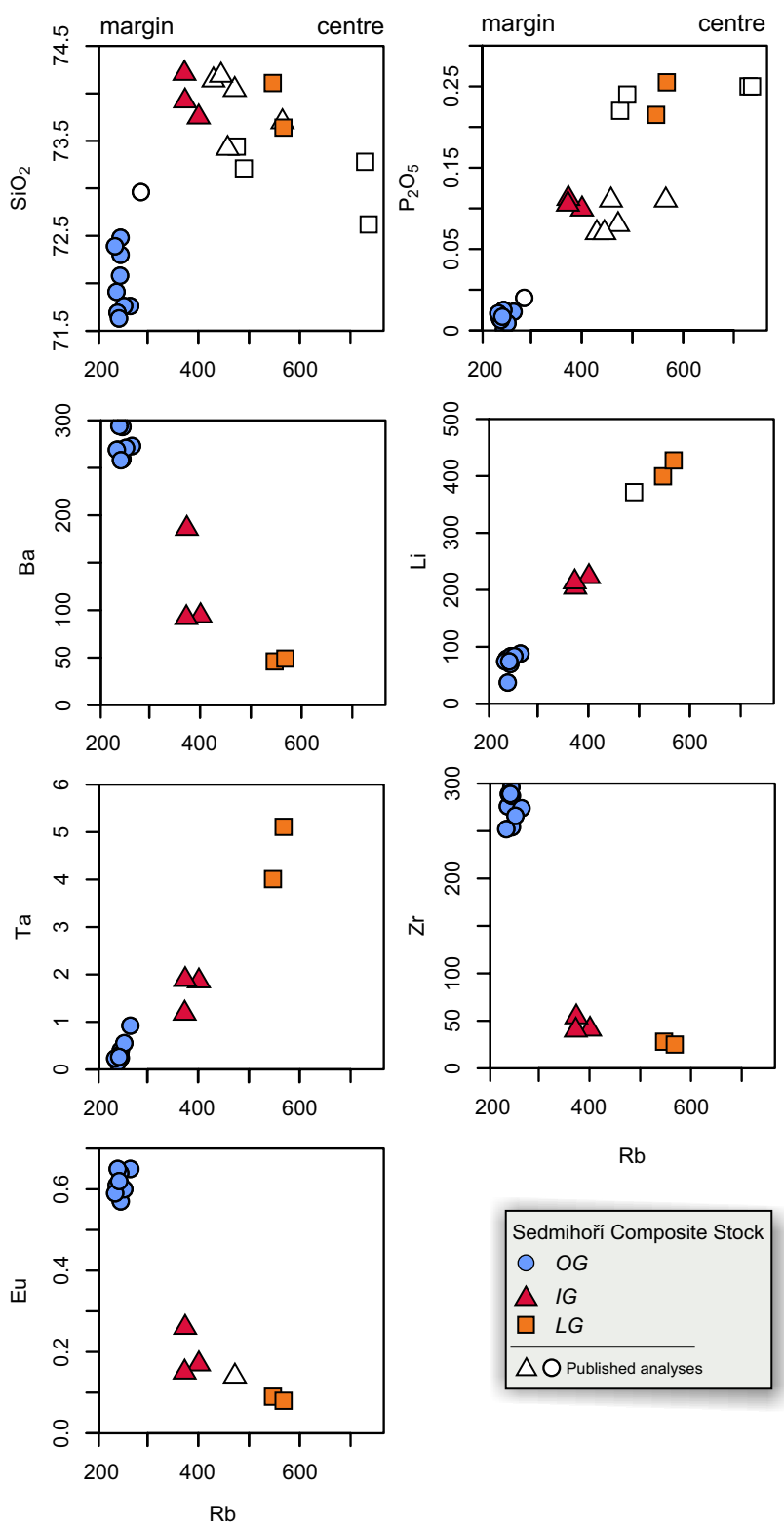

(Finger et al. 1997, 2009). The more extensive southern Saxo-Danubian Granite Belt was created by two magmatic pulses at 330-320 Ma and 317-310 Ma (Siebel et al. 2003; Förster and Romer 2010), perhaps in response to southward progressing mantle delamination (Finger et al. 2009).

The first attempts on dating of the SCS were done by Voves et al. (1997). The samples plotted on an ill-defined isochron of $313 \pm 50 \mathrm{Ma}\left({ }^{87} \mathrm{Sr} /{ }^{86} \mathrm{Sr}_{\mathrm{i}}=0.7213\right)$. However, the current study documents open-system behaviour of the $\mathrm{Sr}-\mathrm{Nd}$ isotopic systems in the SCS. Due to the magma hybridization, any correlations in the ${ }^{87} \mathrm{Rb} /{ }^{86} \mathrm{Sr}$ vs. ${ }^{87} \mathrm{Sr} /{ }^{86} \mathrm{Sr}$ space are likely spurious and the calculated ages with initial ratios are misleading (e.g., Dodson 1982; Wendt 1993).
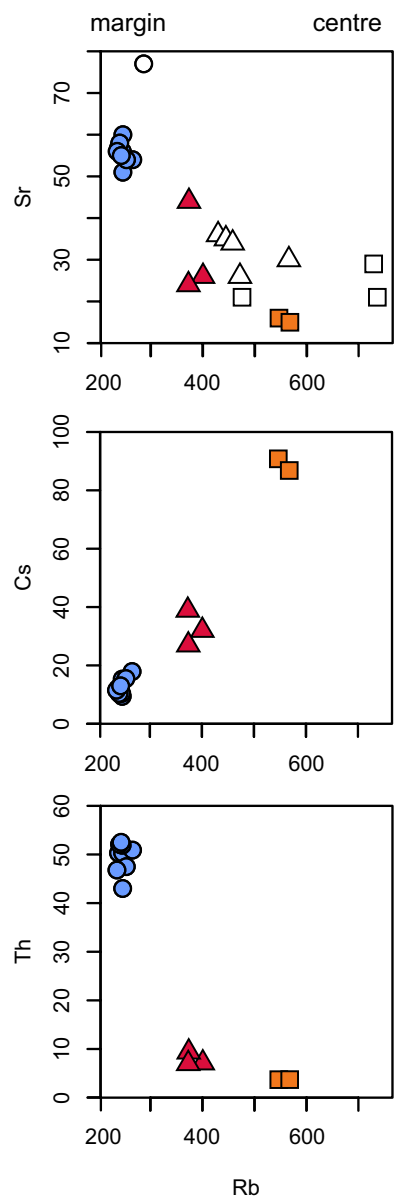

Fig. 9 Binary plots of Rb vs. selected major- and trace-elements (wt. \% and ppm, respectively).

Therefore, it is necessary to employ an alternative geochronological method, e.g. U-Pb dating on zircons. The LA ICP-MS ages reported in this work provide a more realistic age. They indicate an emplacement in an extensional regime of southern Saxo-Danubian Granite Belt, for both main pulses of the SCS nearly simultaneously at c. $326 \mathrm{Ma}$.

\subsection{Conceptual model}

The shallow-level Sedmihoří Stock (SCS), which intruded the Teplá-Barrandian Unit in Middle Carboniferous times, is particularly suitable to address fundamental questions about how zoned plutons are constructed and how long the upper crustal magma chambers remain active. Here we combine all the results into a single model.

Underplating of redwitzites melts, which heated mainly the Neoproterozoic metasediments of the TepláBarrandian Unit during and after the orogenic collapse, generated the first generation of dioritic and granodioritic plutons (e.g., Bor Pluton; Siebel et al. 1999). Similarly, 
Fig. 10 Enlarged portion of the radiometric map of the Czech Republic (Czech Geological Survey - http:// www.geology.cz/extranet-eng/sciencel landscape-vulnerability/radon) (inset) showing high radioactivity of $\mathrm{Th}, \mathrm{U}$, and $\mathrm{K}$ in the Sedmihoři Composite Stock and the nearby Bor Pluton. Note that the average Th concentrations in the OG pulse are significantly higher than those in the IG.

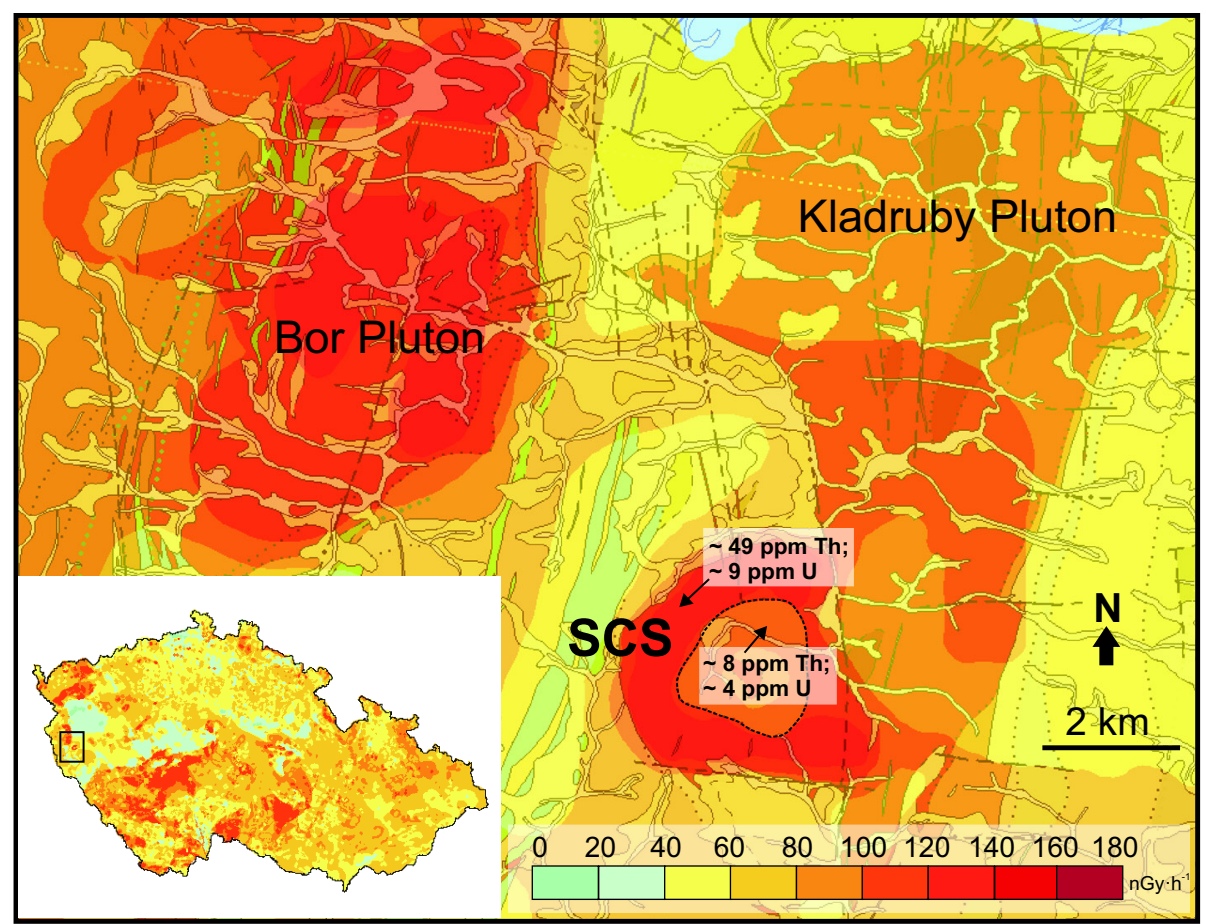

al. 2015), whereby the rapid crystallization and vesiculation within the recharge magma drive the evolved liquid into the overlying silicic magma reservoir. Based on mineral assemblages and the presence of miarolitic cavities, the depth of emplacement was less than $3 \mathrm{~km}$ (corresponding to a pressure of $c .1 .5 \mathrm{kbar}$ ).

\section{Conclusions}

- The Sedmihoří Stock (SCS) in the Teplá-Barrandian Unit, Bohemian Massif, represents a silica-rich and subaluminous to strongly peraluminous, geochemically evolved, normally-zoned granitoid pluton, consisting of three nested magma pulses/magmatic units. These are, from the margin to the centre, outer porphyritic biotite monzogranite (OG), inner biotite-muscovite monzogranite (IG), and innermost tourmaline-muscovite leucogranite (LG).

- Both the outer and inner magma pulses (OG and IG) were nearly coeval, as supported by new $\mathrm{U}-\mathrm{Pb}$ zircon ages (OG: $326.2 \pm 1.2 \mathrm{Ma}$ and IG: $326.5 \pm 1.2 \mathrm{Ma}$ ), which are identical within errors.

- At the macro and micro-scale, the textures are exclusively magmatic, Bt and Fsp grains have euhedral to subhedral shapes, interstitial Qtz is not recrystallized. The main rock-forming minerals exhibit no effects of solid-state crystal deformation.

- The granite contains numerous accessory minerals (e.g., apatite, zircon, monazite, andalusite, thorite or 


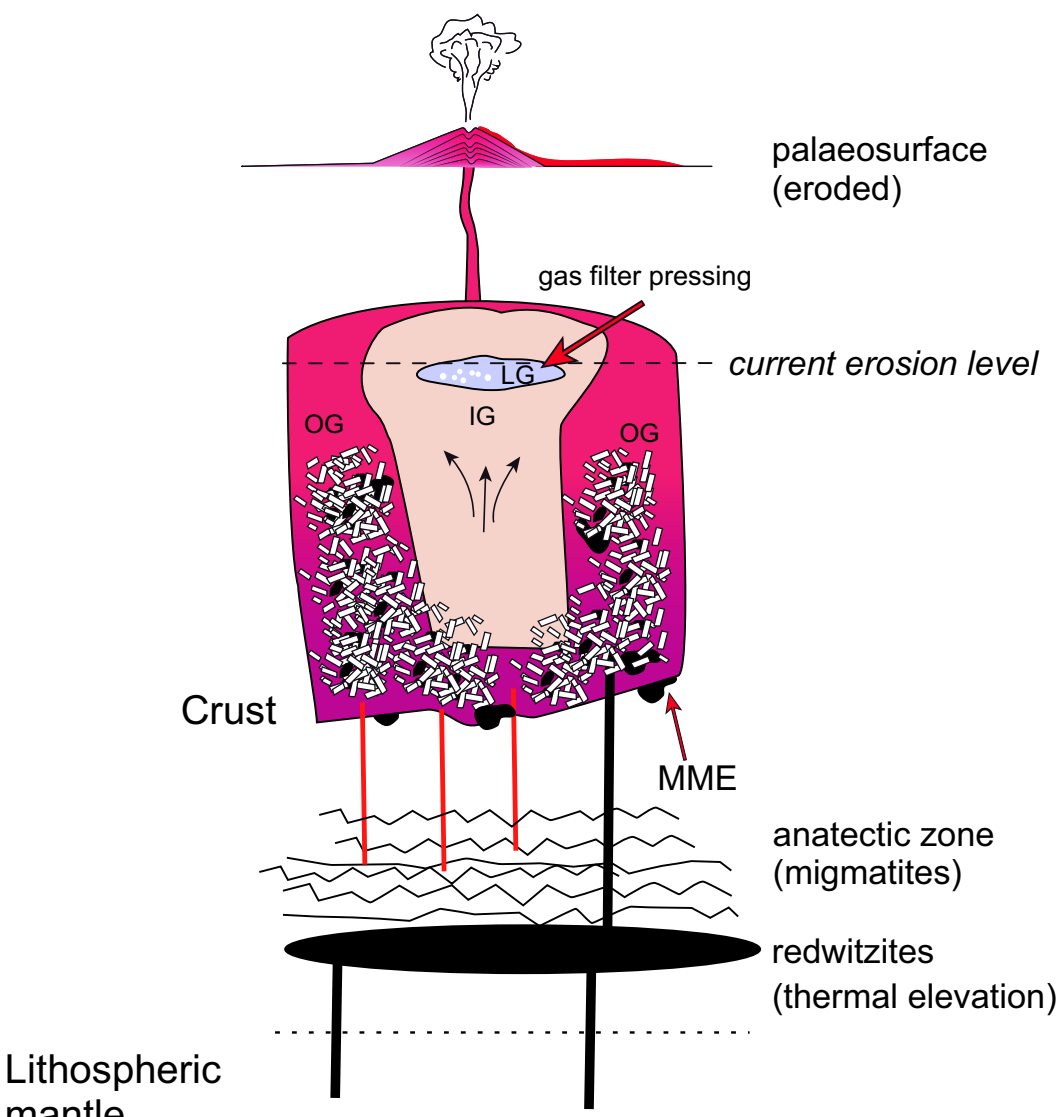
mantle

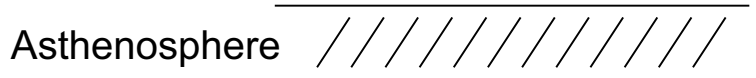

tourmaline). The mineral assemblages provide good evidence for the evolution of the magma, with $\mathrm{IG}+$ LG being more evolved than OG.

- Normal zoning is manifested by mineral chemistry of major rock-forming and accessory minerals, whereby the original mineral assemblages in each of the magmatic units reflect the evolution of magma from the margin to the centre of the stock. Also, petrography captures significant differences between all three pulses, e.g., the inwards decreasing modal proportion of K-feldspar phenocrysts. Last but not least, the normal zoning is supported by whole-rock geochemical trends such as an inward increase in $\mathrm{Li}, \mathrm{Cs}$ and $\mathrm{Rb}$, or decrease in $\mathrm{Ba}, \mathrm{Sr}, \mathrm{Zr}$, Th and $\mathrm{REE}$.

- The magma parental to the SCS originated by anatexis of largely metasedimentary material of the Teplá-Barrandian Unit, Neoproterozoic, or (more likely) Cambrian in age.

- Mafic enriched-mantle derived magmas (redwitzites) played a very important petrogenetic role. They likely provided not only the heat needed for the anatexis but also variably directly contributed material via magma mixing processes. The hybridization was particularly significant for the origin of the outer (OG) unit, which is rich in mafic microgranular enclaves and
Fig. 11 Cartoon illustrating the proposed development of the Sedmihorí Composite Stock at c. $326 \mathrm{Ma}$.

whose $\mathrm{Sr}$ is the least and $\mathrm{Nd}$ most radiogenic within the SCS.

- The main process for LG formation was probably the gas-driven filter pressing. This process occurs during the crystallization of intrusive igneous bodies in which the interstitial liquid is separated from the crystals by pressure. As crystals grow and accumulate in a magmatic body, a crystal mush may be formed, with the remaining liquid distributed in the interstices.

Acknowledgements. An anonymous reviewer, Marlina Elburg and Wolfgang Siebel, as well as handling editor Milan Kohút, are gratefully acknowledged for their speedy and helpful comments and suggestions greatly improving the manuscript. The authors are grateful to Jiři Žák for collaboration in the field and, in particular, expert guidance on structural geology, Petr Gadas and František Laufek for measurement and recalculation of mineral chemistry for the SCS. Special thanks are due to Martin Racek for CL zircon imaging. We acknowledge the support by the Grant Agency of the Czech Republic (GAČR, No. 18-24378S to V. Janoušek and No. P210/11/1168 to J. Žák), and Charles University in Prague Operational Programmes OPPK CZ.2.16/3.1.00/21516; Center for Geosphere Dynamics (UNCE/SCI/006). 
Electronic supplementary material. Supplementary representative mineral compositions and complete $\mathrm{U}-\mathrm{Pb}$ data for dated zircons from the Sedmihoří Composite Stock are available online at the Journal web site (http://dx.doi. org/10.3190/jgeosci.294).

\section{References}

Ackerman L, KrŇAnská M, Siebel W, Strnad L (2010) Geochemistry of the Drahotín and Mutěnín intrusions, West Bohemian shear zone, Bohemian Massif: contrasting evolution of mantle-derived melts. Mineral Petrol 99: 185-199

Ali-BIK MW (1996) Kladruby Magmatic Complex - Its Geochemistry, Petrology and Tectonic Setting. Unpublished Ph.D. thesis, Charles University, Prague, pp 1-137

BARbarin B, DidiER J (1992) Genesis and evolution of mafic microgranular enclaves through various types of interaction between coexisting felsic and mafic magmas. Trans Roy Soc Edinb, Earth Sci 83: 145-153

Bonin B, JANOUŠEK V, MoYen JF (in print) Chemical variation, modal composition and classification of granitoids. In: JANOUŠEK V, Bonin B, COLlins WJ, FARINA F, Bowden P (EDS) Post-Archean Granitic Rocks: Contrasting Petrogenetic Processes and Tectonic Environments. Geological Society of London Special Publications 491, doi 10.1144/SP491-2019-138

BoYNTON WV (1984) Cosmochemistry of the rare earth elements: meteorite studies. In: HENDERSON P (ed) Rare Earth Element Geochemistry. Elsevier, Amsterdam, pp 63-114

CANDEla PA (1997) A review of shallow, ore-related granites: textures, volatiles, and ore metals. J Petrol 38: 1619-1633

ChÁв J, STrÁník Z, Eliáš M (2007) Geological map of the Czech Republic 1:500 000. Czech Geological Survey, Prague (in Czech)

Chappell BW (1999) Aluminium saturation in I- and S-type granites and the characterization of fractionated haplogranites. Lithos 46: 535-551

Chen F, Siebel W (2004) Zircon and titanite geochronology of the Fürstenstein granite massif, Bavarian Forest, NW Bohemian Massif: pulses of the late Variscan magmatic activity. Eur J Mineral 16: 777-788

DALLMEYER RD, URBAN M (1998) Variscan vs Cadomian tectonothermal activity in northwestern sectors of the Teplá-Barrandian Zone, Czech Republic: constraints from ${ }^{40} \mathrm{Ar} /{ }^{39} \mathrm{Ar}$ ages. Geol Rundsch 87: 94-106

Debon F, Le Fort P (1983) A chemical-mineralogical classification of common plutonic rocks and associations. Trans Roy Soc Edinb, Earth Sci 73: 135-149

Dempíroví L (2010) The evaluation of precision and relative error of the main components of silicate analyses in Central Laboratory of the CGS. Zpr geol Výzk v Roce 2009 326-330 (in Czech)
Dodson MH (1982) On "spurious" correlations in $\mathrm{Rb}-\mathrm{Sr}$ isochron diagrams. Lithos 15: 215-219

DöRR W, ZULAUF G (2010) Elevator tectonics and orogenic collapse of a Tibetan-style plateau in the European Variscides: the role of the Bohemian shear zone. Int J Earth Sci 99: 299-325

Drost K (2008) Sources and geotectonic setting of Late Neoproterozoic-Early Palaeozoic volcano-sedimentary successions of the Teplá-Barrandian Unit (Bohemian Massif): evidence from petrographical, geochemical, and isotope analyses. Geol Saxon 54: 1-168

Drost K, Romer RL, Linnemann U, Fatka O, Kraft P, MAREK J (2007) Nd-Sr-Pb isotopic signatures of Neoproterozoic-Early Paleozoic siliciclastic rocks in response to changing geotectonic regimes: a case study from the Barrandian area (Bohemian Massif, Czech Republic). In: Linnemann U, Nance RD, Kraft P, Zulauf G (eds) The Evolution of the Rheic Ocean: From Avalonian-Cadomian Active Margin to Alleghenian-Variscan Collision. Geological Society of America Special Papers 423: 191-208

DuDEK A (1957) Sedmihoří - dissected composite stock. Čas Čs spol zeměp 62: 206-209 (in Czech)

Finger F, Roberts MP, Haunschmid B, Schermaier A, STEYRER HP (1997) Variscan granitoids of central Europe: their typology, potential sources and tectonothermal relations. Mineral Petrol 61: 67-96

Finger F, Gerdes A, René M, Riegler G (2009) The Saxo-Danubian Granite Belt: magmatic response to postcollisional delamination of mantle lithosphere below the southwestern sector of the Bohemian Massif (Variscan Orogen). Geol Carpath 60: 205-212

Förster HJ, ROMER RL (2010) Carboniferous magmatism. In: Linnemann U, Romer RL (eds) Pre-Mesozoic Geology of Saxo-Thuringia - from the Cadomian Active Margin to the Variscan Orogen. Schweizerbart, Stuttgart, pp 287-308

Geake JE, Walker G, Telfer DJ (1977) The cause and significance of luminescence in lunar plagioclase. Phil Trans Roy Soc London A285: 403-408

Gerdes A, ZeH A (2006) Combined U-Pb and Hf isotope LA-(MC-)ICP-MS analyses of detrital zircons: comparison with SHRIMP and new constraints for the provenance and age of an Armorican metasediment in Central Germany. Earth Planet Sci Lett 249: 47-61

GERDES A, ZEH A (2009) Zircon formation versus zircon alteration - new insights from combined $\mathrm{U}-\mathrm{Pb}$ and $\mathrm{Lu}-\mathrm{Hf}$ in-situ LA-ICP-MS analyses, and consequences for the interpretation of Archean zircon from the Central Zone of the Limpopo Belt. Chem Geol 261: 230-243

HaJnÁ J, ŽÁK J, KaChlíK V, CHADIMa M (2012) Deciphering the Variscan tectonothermal overprint and deformation partitioning in the Cadomian basement of the Teplá-Barrandian Unit, Bohemian Massif. Int J Earth Sci 101: 1855-1873 
Hajná J, Žák J, Kachlík V, DörR W, Gerdes A (2013) Neoproterozoic to early Cambrian Franciscan-type mélanges in the Teplá-Barrandian Unit, Bohemian Massif: evidence of modern-style accretionary processes along the Cadomian active margin of Gondwana? Precambr Res 224: 653-670

Holl PK, von Drach V, Müller-Sohnius D, Köhler H (1989) Caledonian ages in Variscan rocks: $\mathrm{Rb}-\mathrm{Sr}$ and $\mathrm{Sm}-\mathrm{Nd}$ isotopic variations in dioritic intrusives from the northwestern Bohemian Massif, West Germany. Tectonophysics 157: 179-194

Hoskin PWO, Kinny PD, Wyborn D, Chappell BW (2000) Identifying accessory mineral saturation during differentiation in granitoid magmas: an integrated approach. J Petrol 41: 1365-1396

IRBER W (1999) The lanthanide tetrad effect and its correlation with $\mathrm{K} / \mathrm{Rb}, \mathrm{Eu} / \mathrm{Eu}^{*}, \mathrm{Sr} / \mathrm{Eu}, \mathrm{Y} / \mathrm{Ho}$, and $\mathrm{Zr} / \mathrm{Hf}$ of evolving peraluminous granite suites. Geochim Cosmochim Acta 63: 489-508

JACOBSEN SB, WaSSERBURG GJ (1980) Sm-Nd isotopic evolution of chondrites. Earth Planet Sci Lett 50: 139-155

JANOUŠEK V (2006) Saturnin, R language script for application of accessory-mineral saturation models in igneous geochemistry. Geol Carpathica 57: 131-142

JANOUŠEK V, ROGERS G, BOWES DR (1995) Sr-Nd isotopic constraints on the petrogenesis of the Central Bohemian Pluton, Czech Republic. Geol Rundsch 84: 520-534

JANOUŠEK V, FARROW CM, ERBAN V (2006) Interpretation of whole-rock geochemical data in igneous geochemistry: introducing Geochemical Data Toolkit (GCDkit). J Petrol 47: 1255-1259

Janoušek V, Farrow CM, Erban V, Trubač J (2011) Brand new Geochemical Data Toolkit (GCDkit 3.0) - is it worth upgrading and browsing documentation? (Yes!). Geol Výzk Mor Slez 18: 26-30

KošLer J, KonopáseK J, Sláma J, VRána S (2013) U-Pb zircon provenance of Moldanubian metasediments in the Bohemian Massif. J Geol Soc, London 171: 83-95

KováŘíková P, Siebel W, Jelínek E, ŠTeMProk M, KaChLíK V, Holub FV, Blecha V (2007) Petrology, geochemistry and zircon age for redwitzite at Abertamy, NW Bohemian Massif (Czech Republic): tracing the mantle component in Late Variscan intrusions. Chem Erde 67: 151-174

KováŘíkoví P, Siebel W, JelíNeK E, ŠTEMPROK M, KaChlíK V, Holub FV, Blecha V (2010) Dioritic intrusions of the Slavkovský les (Kaiserwald), Western Bohemia: their origin and significance in late Variscan granitoid magmatism. Int J Earth Sci 99: 545-565

Kularatne K, Audétat A (2014) Rutile solubility in hydrous rhyolite melts at $750-900^{\circ} \mathrm{C}$ and $2 \mathrm{kbar}$, with application to titanium-in-quartz (TitaniQ) thermobarometry. Geochim Cosmochim Acta 125:196-209

Lardeaux JM, Schulmann K, Faure M, Janoušek V, LeXa O, Skrzypek E, Edel JB, ŠtíPská P (2014) The
Moldanubian Zone in French Massif Central, Vosges/ Schwarzwald and Bohemian Massif revisited: differences and similarities. In: Schulmann K, Martínez Catalán JR, Lardeaux JM, Janoušek V, Oggiano G (eds) The Variscan Orogeny: Extent, Timescale and the Formation of the European Crust. Geological Society, London, Special Publications 405: 7-44

LiEw TC, Hofmann AW (1988) Precambrian crustal components, plutonic associations, plate environment of the Hercynian Fold Belt of central Europe: indications from a Nd and Sr isotopic study. Contrib Mineral Petrol 98: 129-138

LuDwIG KR (2003) Isoplot/Ex version 3.00. A Geochronological Toolkit for Microsoft Excel, User's Manual. Berkeley Geochronology Center Special Publications 4, Berkeley, pp 1-70

Lugmair GW, Marti K (1978) Lunar initial ${ }^{143} \mathrm{Nd} /{ }^{144} \mathrm{Nd}$ : differential evolution of the lunar crust and mantle. Earth Planet Sci Lett 39: 349-357

Masuda A, Kawakami O, Dohmoto Y, Takenaka T (1987) Lanthanide tetrad effects in nature: two mutually opposite types, W and M. Geochem J 21: 119-124

MerLet C (1992) Quantitative electron probe microanalysis: new accurate $\varphi(\rho Z)$ description. Mikrochimica Acta 12: $107-115$

MielKe P, WinkLer HGF (1979) Eine bessere Berechnung der Mesonorm für granitische Gesteine. Neu Jb Mineral, Mh 1979: 471-480

Míková J, Denková P (2007) Modified chromatographic separation scheme for $\mathrm{Sr}$ and $\mathrm{Nd}$ isotope analysis in geological silicate samples. J Geosci 52: 221-226

Miller CF, McDowell SM, Mapes RW (2003) Hot and cold granites: implications of zircon saturation temperatures and preservation of inheritance. Geology 31: 529-532

Millonig LJ, Gerdes A, Groat LA (2012) U-Th-Pb geochronology of meta-carbonatites and meta-alkaline rocks in the southern Canadian Cordillera: a geodynamic perspective. Lithos 152: 202-217

MonTEL J-M (1993) A model for monazite/melt equilibrium and application to the generation of granitic magmas. Chem Geol 110: 127-146

Nance RD, Murphy JB, Strachan RA, Keppie JD, Gutiérrez-Alonso G, Fernández-SuÁrez J, QuesadA C, Linnemann U, D’Lemos RS, Pisarevsky SA (2008) Neoproterozoic-early Palaeozoic tectonostratigraphy and palaeogeography of the peri-Gondwanan terranes: Amazonian v. West African connections. In: ENNIH N, LIÉGEOIS J-P (eds) The Boundaries of the West African Craton. Geological Society London Special Publications 297: $345-383$

Nance RD, GutiérReZ-Alonso G, KepPie JD, LinnemanN U, Murphy JB, Quesada C, Strachan RA, Woodcock NH (2010) Evolution of the Rheic Ocean. Gondwana Res 17:194-222 
NeuŽIloví M, Vejnar Z (1966) The geology and petrography of rocks of the Kladruby Massif. Sbor geol Věd, Geol 11: 7-31 (in Czech)

PeCCerillo A, TAYlor SR (1976) Contributions to mineralogy and geochemistry of Eocene calc-alkaline volcanic rocks from the Kastamonu area, northern Turkey. Contrib Mineral Petr 81: 63-81

Pin C, Waldhausrová J (2007) Sm-Nd isotope and trace element study of Late Proterozoic metabasalts ("spilites") from the Central Barrandian Domain (Bohemian Massif, Czech Republic). In: Linnemann U, Nance RD, Kraft P, Zulauf G (eds) The Evolution of the Rheic Ocean: From Avalonian-Cadomian Active Margin to Alleghenian-Variscan Collision. Geological Society of America Special Papers 423: 231-247

Pin C, Zalduegui JS (1997) Sequential separation of light rare-earth elements, thorium and uranium by miniaturized extraction chromatography: application to isotopic analyses of silicate rocks. Anal Chim Acta 339: 79-89

Pin C, Briot D, Bassin C, Poitrasson F (1994) Concomitant separation of strontium and samarium-neodymium for isotopic analysis in silicate samples, based on specific extraction chromatography. Anal Chim Acta 298: 209-217

Pistone M, Blundy JD, Brooker RA (2015) Textural and chemical consequences of interaction between hydrous mafic and felsic magmas: an experimental study. Contrib Mineral Petrol 171: 1-21

Schulmann K, Konopásek J, Janoušek V, Lexa O, LARDEAUX JM, EdEl JB, ŠTíPSKÁ P, UlRich S (2009) An Andean type Palaeozoic convergence in the Bohemian Massif. C R Geosci 341: 266-286

Shand SJ (1943) Eruptive Rocks: Their Genesis, Composition, and Classification, with a Chapter on Meteorites. J. Wiley \& Sons, New York, pp 1-444

Siebel W (1993) Geochronology of the Leuchtenberg granite and associated redwitzites. KTB Report 93:2, 411-416

Siebel W, Trzebski R, Stettner G, Hecht L, Casten U, HöHNDORF A, MüLLER P (1997) Granitoid magmatism of the NW Bohemian Massif revealed: gravity data, composition, age relations and phase concept. Geol Rundsch 86: 45-63

Siebel W, Breiter K, Wendt I, Höhndorf A, HenjesKunst F, RenÉ M (1999) Petrogenesis of contrasting granitoid plutons in western Bohemia (Czech Republic). Mineral Petrol 65: 207-235

Siebel W, Chen F, Satir M (2003) Late Variscan magmatism revisited: new implications from $\mathrm{Pb}$-evaporation zircon ages on the emplacement of redwitzites and granites in NE Bavaria. Int J Earth Sci 92: 36-53

Siebel W, Reitter E, Wenzel T, Blaha U (2005) Sr isotope systematics of $\mathrm{K}$-feldspars in plutonic rocks revealed by the $\mathrm{Rb}-\mathrm{Sr}$ microdrilling technique. Chem Geol 222: 183-199
Siebel W, Thiel M, Chen F (2006) Zircon geochronology and compositional record of late- to post-kinematic granitoids associated with the Bavarian Pfahl zone (Bavarian Forest). Mineral Petrol 86: 45-62

Sisson TW, BACON CR (1999) Gas-driven filter pressing in magmas. Geology 27: 613-616

Sláma J, Košler J, Condon DJ, Crowley JL, Gerdes A, Hanchar JM, Horstwood MSA, Morris GA, Nasdala L, Norberg N, Schaltegger U, Schoene B, Tubrett MN, Whitehouse MJ (2008) Plešovice zircon - a new natural reference material for $\mathrm{U}-\mathrm{Pb}$ and $\mathrm{Hf}$ isotopic microanalysis. Chem Geol 249: 1-35

Smith J V, Stenstrom RC (1965) Electron-excited luminescence as a petrologic tool. J Geol 73: 627-635

SteIGER R, JäGER E (1977) Subcommission on geochronology: convention on the use of decay constants in geo- and cosmochronology. Earth Planet Sci Lett 36: 359-362

StRECKEISEN A (1979) Classification and nomenclature of plutonic rocks. Geol Rundsch 63: 773-786

Streckeisen A, Le Maitre RW (1979) A chemical approximation to the modal QAPF classification of the igneous rocks. Neu Jb Mineral, Abh 136: 169-206

SylVESTER PJ (1998) Post-collisional strongly peraluminous granites. Lithos 45: 29-44

Tanaka T, Togashi S, Kamioka H, Amakawa H, Kagami H, Hamamoto T, Yuhara M, Orihashi Y, Yoneda S, Shimizu H, Kunimaru T, Takahashi K, Yanagi T, Nakano T, Fujimaki H, Shinjo R, Asahara Y, Tanimizu M, DRAGUSANU C (2000) JNdi-1: a neodymium isotopic reference in consistency with LaJolla neodymium. Chem Geol 168: 279-281

TAUBALD H $(2000){ }^{207} \mathrm{~Pb} /{ }^{206} \mathrm{~Pb}$ zircon ages, geochemical and isotope $(\mathrm{Sr}, \mathrm{Nd}, \mathrm{O})$ data from redwitzites in the Fichtelgebirge, NE Bavaria. Münchner Geol Hefte A 28: 53-59

TAYLOR SR, MCLenNan SM (1995) The geochemical evolution of the continental crust. Rev Geophys 33: 241-265

Tomek F, ŽÁ́ J, Chadima M (2015) Granitic magma emplacement and deformation during early-orogenic syn-convergent transtension: the Staré Sedlo complex, Bohemian Massif. J Geodyn 87: 50-66

Vejnar Z (1967) Petrogenetic correlation of some granitic bodies in Western Bohemia. Věst Ústř Úst geol 42: 87-94 (in Czech)

Vejnar Z (1984) Magmatism In: Geology of the Domažlice Area. Czech Geological Survey, Prague, pp 48-83 (in Czech)

Verner K, Žák J, Pertoldová J, Šrámek J, Sedlák J, TRUbaČ J, TÝcové P (2009) Magmatic history and geophysical signature of a post-collisional intrusive center emplaced near a crustal-scale shear zone: the Plechý granite pluton (Moldanubian Batholith, Bohemian Massif). Int J Earth Sci 98: 517-532

Villaseca C, Barbero L, Herreros V (1998) A reexamination of the typology of peraluminous granite 
types in intracontinental orogenic belts. Trans Roy Soc Edinburgh, Earth Sci 89: 113-119

Voves J, Bendl J, Jelínek E, Ali Bik MW (1997) Granitoids of the Kladruby pluton and the Sedmihoří stock (Western Bohemia): geochemistry and geochronology. Acta Univ Carol, Geol 41: 81-89

Vrána S, Blümel P, Petrakakis K (1995) Metamorphic evolution. In: Dallmeyer RD, Franke W, Weber K (eds) Pre-Permian Geology of Central and Eastern Europe. Springer, Berlin, pp 453-466

Wasserburg GJ, Jacobsen SB, DePaolo DJ, McCullOCH MT, WEN T (1981) Precise determination of Sm/ $\mathrm{Nd}$ ratios, $\mathrm{Sm}$ and $\mathrm{Nd}$ isotopic abundances in standard solutions. Geochim Cosmochim Acta 45: 2311-2323

WATSON EB, HARRISON TM (1983) Zircon saturation revisited: temperature and composition effects in a variety of crustal magma types. Earth Planet Sci Lett 64: 295-304

WENDT I (1993) Isochron or mixing line? Chem Geol 104: 301-305

Whitney DL, Evans BW (2010) Abbreviations for names of rock-forming minerals. Amer Miner 95: 185-187

Wiedenbeck M, Allé P, Corfu F, Griffin WL, Meier M, Oberli F, von Quadt A, Roddick JC, SpIegel W (1995) Three natural zircon standards for U-Th-Pb, $\mathrm{Lu}-\mathrm{Hf}$, trace element and REE analyses. Geostand Newsl 19: 1-23
Willmann K (1919) Die Redwitzite, eine neue Gruppe von granitischen Lamprophyren. Z Dtsch geol Gesell 71: 1-33

ZeH A, GeRDes A (2012) U-Pb and Hf isotope record of detrital zircons from gold-bearing sediments of the Pietersburg Greenstone Belt (South Africa) - is there a common provenance with the Witwatersrand Basin? Precambr Res 204-205: 46-56

Zulauf G (1994) Ductile normal faulting along the West Bohemian Shear Zone (Moldanubian/Teplá-Barrandian boundary): evidence for late Variscan extensional collapse in the Variscan Internides. Geol Rundsch 83: 276-292

Zulauf G, Bues C, Dörr W, Vejnar Z (2002) $10 \mathrm{~km}$ minimum throw along the West Bohemian shear zone: evidence for dramatic crustal thickening and high topography in the Bohemian Massif (European Variscides). Int J Earth Sci 91: 850-864

ŽÁK J, Verner K, JANOUŠEK V, Holub FV, KaChlíK V, Finger F, Hajná J, Tomek F, Vondrovic L, Trubač J (2014) A plate-kinematic model for the assembly of the Bohemian Massif constrained by structural relationships around granitoid plutons. In: SCHULMANN K, MARTÍNEZ Catalán JR, LARdeaux JM, JanOuŠEK V, OgGiano G (eds) The Variscan Orogeny: Extent, Timescale and the Formation of the European Crust. Geological Society London Special Publications 405: 169-196 